Article

\title{
The Effects of Health Status on Life Insurance Holdings in 16 European Countries
}

\author{
Saruultuya Tsendsuren ${ }^{1}$, Chu-Shiu Li ${ }^{2, *}$, Sheng-Chang Peng ${ }^{3}$ and Wing-Keung Wong $4,5,6,7$ (i) \\ 1 Business Development Division, Golomt Bank of Mongolia, Ulaanbaatar 15160, Mongolia; \\ saka_can@yahoo.com \\ 2 Department of Risk Management and Insurance, College of Finance and Banking, National Kaohsiung \\ University of Science and Technology, Kaohsiung 824, Taiwan \\ 3 Department of Risk Management and Insurance, School of Management, Ming Chuan University, \\ Taipei 111, Taiwan; scpeng@mail.mcu.edu.tw \\ 4 Department of Finance, College of Management, Fintech Center, and Big Data Research Center, \\ Asia University, Taichung 41354, Taiwan; wong@asia.edu.tw \\ 5 Department of Medical Research, China Medical University, Taichung 404, Taiwan \\ 6 Department of Economics and Finance, Hang Seng Management College, Hong Kong 999077, China \\ 7 Department of Economics, Lingnan University, Tuen Mun, Hong Kong 999077, China \\ * Correspondence: chushiu.li@gmail.com; Tel.: +886-7-601-1000 (ext. 33017)
}

Received: 30 June 2018; Accepted: 19 September 2018; Published: 27 September 2018

\begin{abstract}
This study examines the relationships among three health status indicators (self-perceived health status, objective health status, and future health risk) and life insurance holdings in 16 European countries. Our results show that households with poor self-perceived health status and high future health risk are less likely to purchase life insurance in the entire sample as well as in the subsample for countries with a national health system (NHS). In non-NHS countries, those households that have high future health risk are less inclined to purchase life insurance. In terms of preferences for types of life insurance policies (term life, whole life, both, or none) in the whole sample, poor self-perceived health status and high future health risk are less inclined to hold only term life insurance policy. In addition, poor self-perceived health status and high future health risk have a negative impact on holdings of both types of life insurance. Our findings reveal that there is no adverse selection problem in the life insurance market, especially in European countries with NHS.
\end{abstract}

Keywords: life insurance; term life insurance; whole life insurance; self-perceived health; objective health status; future health risk; SHARE; national health system

JEL Classification: A13; D14; D81; D82; G22

\section{Introduction}

Life insurance has a special standing among households, used to hedge against the loss of income resulting from an unexpected death [1] Life insurance often helps to carry out family responsibilities such as educating children, paying off mortgage or other debt, and providing revenue for survivors [2].

From prior studies on the relationship between health status indicators and medical insurance purchases, poor health status is negatively associated with the purchase of medical insurance in the US [3] and Europe [4]. Buchmueller et al. [5] observe that those with private health insurance have lower hospital utilization than those without private health insurance in Australia. In China, rural residents enrolled in The New Cooperative Medical Scheme have higher probability of shifting from working for others to being self-employed and from being temporarily employed to being self-employed [6]. 
The main purpose of this study is to explore the effects of three health status indicators, self-perceived health status (SPH), objective health status (OHS), and future health risk (FHR) on life insurance holdings in 16 European countries (The detailed definitions of SPH, OHS, and FHR are included in the Section 3). We also investigate the impact of these three health status indicators on the decision to purchase different types of life insurance (term, whole, or both types of life insurance policies). The data used in this study is from the Survey of Health, Aging, and Retirement in Europe (SHARE). Prior literature reveals that different national health systems (NHS) offer differing degrees of risk protection $[7,8]$. Therefore, we examine whether NHS impacts on the relationship between health status and life insurance holdings.

The important contributions of this paper are as follows: First, to the best of our knowledge, this is the first paper to examine the effects of three different health status indicators on the demand for life insurance in European countries. Second, we use SHARE household data from 16 European countries to compare the results of other determinants on life insurance ownership and the types of life insurance, as well as previous studies based on data from only one country. The use of SHARE data represents significant improvements over previous studies based on data from individual countries. Third, we examine and compare the responses of households in NHS and non-NHS countries to explore the effect of NHS on life insurance holdings. Finally, our empirical results may provide policy implications for insurers in European countries in that the marketing strategies for life insurance should consider not only demographic factors, but also household health status and national health insurance coverage.

Our findings clearly support our hypotheses that SPH and high FHR are negatively associated with the decision to hold life insurance in the pooled data and in the subsample of NHS countries (In our regression models, when we consider these three health status indicators one by one, each has negative correlation with life insurance holdings. However, when we consider the three health status indicators together, the coefficient of OHS becomes insignificantly different from zero). However, among households in non-NHS countries, only FHR has a negative effect on life insurance purchase. Moreover, elderly households with high FHR have high probability to hold life insurance in the whole sample, as well as in the subsample of non-NHS countries.

There are some interesting results in terms of the demand for different types of life insurance (term life only, whole life only, or both types) in the whole sample. The estimated marginal effects reveal that all three health status indicators are negatively related to holding only term life policies (There are similar regression results for life insurance holdings. When we consider the three health status indicators together, there is no effect of OHS on the holding of term life insurance only). Households with poor SPH or high FHR are less likely to own both types. However, no health status indicator is related to households with whole life only. Our empirical evidence may provide policy implications for insurers in European countries. For example, marketing strategies should consider not only demographic factors but also household health status indicators and NHS. Finally, our empirical evidence reveals that there is no existing adverse selection problem in life insurance markets especially among NHS countries in Europe.

The rest of this paper is organized as follows: Section 2 provides a review of existing literature and hypothesis development. Section 3 includes a discussion of the research methods. In Section 4, we present the empirical results. Finally, Section 5 is the conclusion.

\section{Literature Review and Hypothesis Development}

This section begins with a brief review of the literature followed by the hypotheses tested in this study. One stream of the literature on life insurance demand focuses on aggregated country analysis and concludes that income per capita, young dependency ratio, social security system, interest rate, and inflation are the main factors that affect the demand for life insurance in different countries [9-12]. Another stream of the literature uses household or individual data for one specific country to determine the demographic factors (such as age, education, marital status, numbers of children) and economic factors (such as income and net wealth) that are associated with the decision 
to hold life insurance $[13,14]$. However, very few papers examine the association between health status and the holding of life insurance. Fang and Kung [15] use eight health conditions to define individual health status, including high blood pressure, diabetes, cancer, lung disease, heart disease, stroke, psychological disorder, and arthritis. They demonstrate that healthy individuals are more likely to purchase life insurance than unhealthy individuals in the US.

\subsection{Health Status Indicators and Life Insurance Holding Behaviour}

The concept of health encompasses more than the absence of disease. It includes social, psychological, and economic well-being [16]. Good health indicates satisfaction with life and general acceptance, while poor health refers to a low quality of life or dissatisfaction with life. Furthermore, economic or social factors are the main determinants of good health [16]. Being married and effective health care have the strongest impact on people's positive perceptions of health [17].

The subjective measure of health status is SPH, which refers to a single-item health measure in which individuals rate the current status of their own health on a five-point scale from excellent (or very good) to very poor. Some indicators provide direct evidence of the health status of individuals, including previous and current diseases (diagnosed by physicians), collectively termed OHS.

It is well known that elderly perceiving their health in positive terms tend to overestimate their health, while others tend to report poorer health than those with similar OHS [18]. Thus, the relationship between SPH and OHS is complex. Individuals with poor SPH and high FHR should anticipate higher out-of-pocket health expenditures than similar individuals with low FHR. Individuals are generally unable to dynamically insure against FHR and medical expenditure risk [19].

Some empirical studies identify health risks as an important factor in precautionary participation in the financial market $[7,8,20-24]$. With respect to health status, most of the previous literature, except Atella et al. [7], considers the effects of current health status on portfolio decision, without investigating the roles of FHR and OHS. The elderly are less likely to increase income risks when they face a much higher health risk. In other words, when health risks cannot be easily avoided, investors may tend to underestimate their exposure to avoidable risks and financial risks.

\subsection{Hypothesis Development}

\subsubsection{Health Status and Life Insurance Purchase}

In real life, insured people may overstate their health condition and hide some information related to poor health. Therefore, in the underwriting process, life insurance premiums are normally based on two risk factors, gender and age, which may not reflect actuarial life insurance premiums.

Compared with SPH, OHS is a more realistic method of expressing an individual's health status, and can serve as a global measure [18]. It is common for insured to be required to have a health examination or to submit medical reports to the insurer during the process of underwriting under certain conditions, such as above a certain age or with higher coverage. This implies that households with higher health risks (OHS or FHR) pay higher life insurance premiums based on their real health condition. Although the purchase date of life insurance is not included in SHARE data, our study sample consists of households with members who are at least 50 years old. Thus, we expect that most face the uncertainty of adjusted premium through the process of underwriting when they purchase life insurance. We expect a lower probability of purchasing a life insurance policy when an individual has a higher OHS or FHR and, thus, we set the following hypothesis:

Hypothesis 1. Among three health status indicators (SPH, OHS, and FHR), OHS or FHR is negatively associated with life insurance holdings.

The perception of health risk is not only a function of current and expected health status, but also of the extent of national health insurance coverage. Atella et al. [7] demonstrate that households in 
countries with a less protective healthcare system, based on background risk and poor SPH, have less incentive to invest in risky financial assets. In such cases, the decision to hold risky assets is driven by SPH rather than OHS, which is consistent with the theoretical underpinnings of background risk. In addition to current perceived health, Atella et al. [7] find that households consider FHR in their financial portfolios, especially in non-NHS countries. This suggests an important role for NHS in shaping household portfolio decisions.

Thus, the aims of this paper are to further examine the role of NHS and to investigate the differences between NHS and non-NHS countries. We expect that households with poor health status are less likely to buy life insurance in countries with NHS, and, thus, we set the following hypothesis:

Hypothesis 2. By examining the impact of NHS, all three health status indicators (SPH, OHS, and FHR) are negatively associated with life insurance holdings, especially in NHS countries.

\subsubsection{Other Factors and Life Insurance Purchases}

\section{Education}

Most previous studies show a positive relationship between educational level and life insurance demand [10]. Li et al. [11] demonstrate that educational level is positively related to life insurance demand in OECD countries (including 30 European countries). However, Çelik and Kayali [25] find a negative relationship between educational level and life insurance purchases from 2000 to 2006 in European countries. In this study, we expect a positive association between educational level and life insurance holdings in European countries.

\section{Bequest Motive}

The main function of life insurance is to provide funds for carrying out family responsibilities in the event of the premature death of a wage earner. The proxies of the bequest motive contain three variables: being married, having children, and a subjective preference for leaving bequests. Life insurance policies (especially term life insurance) are mainly bought for bequest purposes. According to a review by Zietz [26], two papers reveal a negative connection between marital status and life insurance. In contrast, two studies find a positive association between the bequest motive and personal life insurance demand. Inkmann and Michaelides [27] reveal a positive correlation between the demand for life insurance and bequest motive. A more recent study highlights the positive correlation between family members and life insurance demand [28]. Based on this empirical evidence, we expect positive effects of marital status and with child on the demand for life insurance.

Income and Net Wealth

Income is probably the most influential determinant for purchasing life insurance in terms of the ability to pay premiums. Thus, much of the literature shows positive correlation between income level and life insurance demand [26,29]. Çelik and Kayali [25] also find that income is the central variable which affects life insurance purchases in European countries. However, from a review of 12 studies by Zietz [26] regarding the association between wealth and consumption of life insurance, there is no consistent result or correlation. Heo et al. [30] indicate that the amount of insurance purchase increases with net wealth. Shi et al. [28] indicate that both household current income and wealth have positive correlations with life insurance holdings.

Pension

Few studies analyse the relationship between public pension system and life insurance consumption. Among households with low public pension, purchasing life insurance can serve to increase bequest. Thus, there is a higher tendency for self-employed individuals in Germany who 
are not covered by the public pension system to buy life insurance and accumulate their wealth to reach higher wealth levels [31]. Andersson and Eriksson [32] also show that compulsory pension reduces the demand for life insurance. Sauter et al. [13] indicate that the impact of public pension as an income source on life insurance demand depends on the relative levels of savings and bequest motive.

\section{Life Expectancy}

$\mathrm{Li}$ et al. [11] indicate that longer life expectancy is associated with a lower demand for life insurance in OECD countries. In contrast, Inkmann and Michaelides [27] find that term life insurance purchases decrease with higher survival probabilities among elderly households in England. Beck and Webb [9] observe that life expectancy has no connection with life insurance consumption across countries. Thus, we expect the effect of life expectancy on life insurance purchase to be uncertain.

\section{Religion}

Based on the literature, the effect of religion on the demand for life insurance varies. Burnett and Palmer [33] indicate that households without religious beliefs have a more positive attitude toward purchasing higher levels of life insurance coverage than those with religious beliefs in the US. In addition, life insurance consumption is significantly lower in Islamic nations [34] and Muslim populations [9,29]. However, Loke and Goh [35] (2011) consider ethnicity as the proxy for religion and demonstrate that both Indians and Chinese are inclined to hold life insurance policies compared to Malays. Thus, we expect that the effect of religion on the demand for life insurance varies due to the differences in religious beliefs (In the SHARE questionnaire, there is generalization of questions pertaining to religious participation. Therefore, religions are not separated into specific categories).

\section{Materials and Methods}

\subsection{Materials}

This study uses data from Wave 4 (2010-2011) of SHARE, a survey of households from 16 European countries. It also contains previous information from Wave 1 and Wave 2 (Data from Wave 1 (2004) of SHARE is from 11 countries: Austria, Denmark, France, Germany, Greece, Italy, the Netherlands, Spain, Sweden, Switzerland, and Belgium. Three new European Union members, the Czech Republic, Poland, and Ireland, are included in Wave 2 of SHARE (2006-2007). Wave 3 (2008-2009), SHARELIFE, collects detailed retrospective life histories in 13 countries. All questions are standardized across countries, allowing for consistent international comparisons.). The initial data on life insurance holdings is from households in 11 countries in Wave 1 (2004-2005). Any changes in life insurance holding statuses between Wave 2 (2006-2007) and Wave 4 (2010-2011) are noted. In particular, if a household initially has life insurance holdings in Wave 1, but no life insurance holdings in Wave 2, we consider this household as without life insurance in Wave 4. As changes in life insurance holdings are likely to be related to marital status, we use the marital status specified in Wave 4 . In addition, our inference is based on health status measured at the time of the interview, while life insurance purchase is a decision made beforehand.

We analyze the purchasing of life insurance based on the information provided by households in the following 16 countries: Denmark, Sweden, Austria, Belgium, France, Germany, the Netherlands, Switzerland, Poland, the Czech Republic, Italy, Spain, Hungary, Portugal, Slovenia, and Estonia, in Wave 4 (Certain numbers of observations are removed from the panel respondents participating in both waves, particularly for the primary countries Greece and Ireland in which respondents participate in the initial waves but not in Wave 4). SHARE is conducted among households with at least one member aged 32 or more. We focus on the overall financial situation of households and those with respondents who are aged 50 to 90 , eliminating observations with missing values for any of the variables relevant to our analysis. Our overall sample consists of 34,341 households. 
SHARE is an international, multidisciplinary, and balanced longitudinal survey of various countries in Europe, developed to address research issues on aging. As the main structure of the SHARE survey is generic, the instrument is fixed, and all questions are standardized across countries, our findings allow for consistent international comparisons. SHARE provides comprehensive information on standard demographic variables, health, cognition, intensity of social interaction, and a variety of economic and financial variables, including net wealth, gross income, and household total consumption (For all waves, SHARE interviewers conduct computer-assisted personal interviews to collect most of the data. The structure of the computer-assisted personal interviewing instrument is generic, the instrument is fixed, and only the language used varies among the countries. A detailed description of SHARE data and methodology is published in Börsch-Supan, et al. [36]. Data is available to registered users on the SHARE website (http:/ / www.share-project.org)).

In this paper, health risk is evaluated based on medical expenditures, which affect a household's decision to buy life insurance. Health risk is a function of current and expected health statuses and medical expenditures. These depend not only on health risk, but also on health insurance coverage.

To examine how health risk affects life insurance holdings, we classify countries into two groups: (1) with publicly supported NHS, which offers full coverage; and (2) with NHS that does not provide full coverage (non-NHS). Rather, several forms of private health insurance cover medical expenditures. This raises the overall degree of background risk and hence life insurance holdings may decrease. We split the sample using a method similar to that described by Atella et al. [7] and Bressan et al. [8], distinguishing between countries with NHS with full coverage (Sweden, Spain, Italy, Denmark, Czech Republic, Poland, Hungary, Portugal, Slovenia, Estonia) and countries with NHS with partial coverage (Austria, Germany, the Netherlands, France, Switzerland, Belgium).

Consequently, we expect that an important effect of NHS is on the household decision to hold/buy life insurance. This enables us to investigate whether households are willing to buy life insurance when the financial consequences of health risk are diminished by a highly protective NHS.

In this study, household propensity to purchase life insurance is the dependent variable. We then focus on the health status variables: SPH (the overall assessment by respondents of their health in general), OHS (current overall health status based on the number of chronic diseases), and FHR (as measured by average number of risky behaviours and chronic diseases).

Statistical analysis is applied at the household level, based on responses by household financial respondents. Particularly, financial transfer and asset questions are answered by financial respondents on behalf of the household. Life insurance holdings and types of life insurance variables are also based on financial respondents' responses [11].

\subsection{Variables}

This section describes the variables based on the characteristics of the households in the whole sample which includes NHS and non-NHS countries. We define three health status variables (SPH, OHS, and FHR) by following the study of Atella et al. [7] who examine the association between health status and portfolio choices in NHS and non-NHS countries separately.

In addition to examining the effects of health status variables on life insurance holdings, we investigate holdings of three categories of life insurance. Basically, life insurance can be classified into term life and whole life. Term life is insurance with a fixed period without cash value after the policy is terminated, but the policyholder can receive claim payment for certain risks during the policy's effective period. Whole life insurance accumulates cash value during the policy period and pays death benefits if the insured dies.

The variables used in this paper are defined as follows: (The detailed information of all variables in this study is shown in the Appendix A, Table A1.)

Life insurance holding: a dummy variable that equals 1 if household holds life insurance and 0 otherwise.

Types of life insurance: a category variable from 1 to $3(1=$ term, $2=$ whole, $3=$ both $)$. 
SPH dummy: Self-perceived health status, categorical: from 1 "very good" to 5 "very bad". We define $\mathrm{SPH}=1$ if poor self-perceived health (indicating level 3, 4 or 5), SPH = 0 if good health (indicating level 1 or 2 ).

OHS: OHS is a determinant of current overall health status that considers not only SPH status, but also the numbers of chronic diseases. This study looks at eight types of chronic diseases, including high blood pressure, diabetes, cancer, lung disease, heart disease, stroke, psychological disorder, and arthritis. Following the procedure used in Zhang et al. [37], the predicated health indicator is obtained from the following formula. $\hat{\mathrm{H}}_{\mathrm{i}}^{*}$ is re-scaled to value in $[0,1]$ :

$$
\widetilde{\mathrm{H}}_{\mathrm{i}}^{*}=\frac{\hat{\mathrm{H}}_{\mathrm{i}}^{*}-\hat{\mathrm{H}}^{\mathrm{min}}}{\hat{\mathrm{H}}^{\mathrm{max}}-\hat{\mathrm{H}}^{\mathrm{min}}},
$$

where $\hat{\mathrm{H}}^{\max }$ and $\hat{\mathrm{H}}^{\mathrm{min}}$ are, respectively, the largest and the smallest predicted values. The association between life insurance and health can be analysed using the adjusted health indicator $\widetilde{\mathrm{H}}_{\mathrm{i}}^{*}$ as the well-being measurement. Thus, households with poor health are more likely to have higher OHS value (Attela et al. [7] use a more complicated term "weighted number of chronic diseases", where the weights are derived according to the degree of severity of disease and the implied disability [38].).

FHR: FHR is evaluated by increasing function of the average number of risky behaviours (smoking, drinking, and a sedentary lifestyle), the household's Asymptomatic Objective Health Status (measured as the average number of diseases, blood pressure, blood cholesterol, and osteoporosis) and decreasing function of average household grip strength. The higher the score, the greater the number and severity of perceived problems (Readers may refer to Attela et al. [7] for more information on the definition of FHR.).

Age $\geq 65$ : a dummy variable that equals 1 if the age of household respondent is 65 or older and 0 if the age of household respondent is less than 65 .

Higher education: a dummy variable that equals 1 if the number of years of education completed is more than or equal to 10 and 0 otherwise.

Marital status: a scale from 1 to $4(1=$ married, $2=$ divorced, $3=$ widowed and $4=$ never married $)$. With children: a dummy variable that equals 1 if household includes child(ren) and 0 otherwise. Household size: the total number of household members.

Household income per capita: the monthly household income divided by household size.

Net wealth per capita: the monthly household net wealth divided by household size.

Pension: household pension.

Probability of receiving inheritance: the probability of receiving any positive amount of inheritance.

Higher life expectancy: a dummy variable that equals 1 if household expects to live at least 10 years and 0 otherwise.

Social activity: a dummy variable that equals 1 if household has social interaction and 0 otherwise.

Religious participation: a dummy variable that equals 1 if household participates in religious activities and 0 otherwise.

Non-NHS: a dummy variable that equals 1 if household is in non-NHS country and 0 if household is in NHS country.

Health spending from coverage: the country-level data of health spending from government or compulsory schemes.

Out-of-pocket health spending: the country-level data of health spending from voluntary schemes or household out-of-pocket payments.

Future retirement age: the country-level data of the future retirement age for a person who entered the labour force at age 20 (average age if future retirement ages are different from men and women). 
Gross pension replacement rate: the country-level data of the gross pension entitlement divided by gross pre-retirement earnings in term of country level (average value if gross pension replacement rates are different from men and women).

\subsection{Methods}

The following probit model [39] is used to examine whether health status variables are related to life insurance holdings:

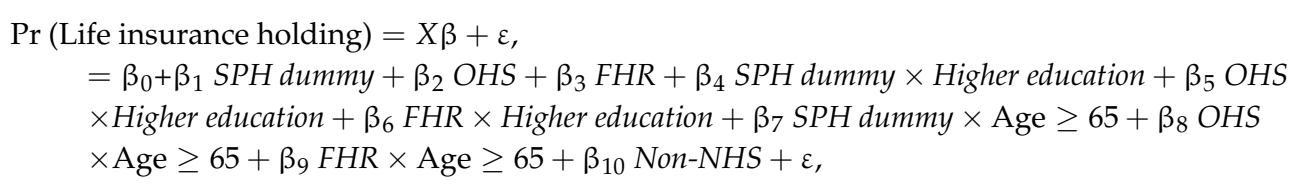

where $\mathrm{Y}$ is the binary response variable, life insurance holdings, and $\beta_{i}(i=1,2,3)$ are the parameters of the three health status variables (SPH dummy, OHS, and $F H R$ ). Interactions of different variables and country variable are included in (1). $\varepsilon$ is an error term.

Atella et al. [7] test the effects of health status variables with age by splitting the data into distinctive groups to analyse whether FHR varies by educational level in terms of portfolio choice. It is interesting to evaluate how the three health status variables (SPH dummy, OHS, and FHR) interact with some demographic characteristics (Education, Age $\geq 65$ ) to impact on the decision to hold life insurance. To examine the holding of life insurance, health status variables are multiplied by educational level and by age for the whole sample and NHS and non-NHS subsamples.

In addition, we follow Barasinska et al. [40] (This study focuses on individual risk attitudes and the composition of financial portfolios in Europe) to examine the marginal effects of $J$ outcomes $(J=4)$ using the following multinomial logit (hump-shaped pattern) regression model to analyse the probability of observing a specific type of life insurance holding, $\operatorname{Prob}\left(Y_{j}\right)$, in the pooled data from all 16 countries:

$$
\operatorname{Prob}\left(Y_{j}\right)=\frac{\exp \left(X \beta_{j}\right)}{\sum_{n=1}^{J} \exp \left(X \beta_{n}\right)} n=0,1,2, \ldots, J ; j=1,2,3,4 ; j \neq n,
$$

in which $X$ is the vector of explanatory variables that include health status variables (SPH dummy, $O H S$, and FHR) and other controls.

\section{Results}

\subsection{Descriptive Statistics}

Table 1 provides the summary statistics and means for all variables. Of the 34,341 households, $21 \%$ hold life insurance in the whole sample, $18.5 \%$ in NHS countries, and $24.3 \%$ in non-NHS countries. In the whole sample, households with life insurance have lower incidences of poor SPH, OHS, and FHR $(29 \%, 0.07$, and 0.25 , respectively) compared with those without life insurance $(43 \%, 0.11$ and 0.33 , respectively). To sum up, these three health status variables are significantly lower among those with life insurance than among those without life insurance in both NHS and non-NHS countries.

In general, younger age (50-64 compared to 65 and above), higher educational level, married status, with children, larger household, higher income and net wealth, lower pension, lower health spending from coverage, lower out-of-pocket health spending, lower future retirement age, lower gross pension replacement rate, higher probability of receiving inheritance, higher life expectancy ( $50 \%$ or higher), socially active, and more religious are more strongly associated with holding life insurance. However, households with certain religious beliefs tend to have life insurance holdings only in countries with NHS (Table 1). 
Table 1. Demographic and economic characteristics of holding life insurance in NHS countries, Age 50+.

\begin{tabular}{|c|c|c|c|c|c|c|c|c|c|c|}
\hline & & \multicolumn{2}{|c|}{ Whole $(\mathrm{N}=34,341)$} & \multirow{3}{*}{$p$-Value } & \multicolumn{2}{|c|}{ NHS $(\mathrm{N}=19,383)$} & \multirow{3}{*}{$p$-Value } & \multicolumn{2}{|c|}{ Non-NHS $(N=14,958)$} & \multirow{3}{*}{$p$-Value } \\
\hline & & with LI & without LI & & with LI & without LI & & with LI & without LI & \\
\hline & & $7216(21 \%)$ & $27,125(79 \%)$ & & $3587(18.5 \%)$ & $15,796(81.5 \%)$ & & $3629(24.3 \%)$ & $11,329(75.7 \%)$ & \\
\hline \multicolumn{11}{|l|}{ Health variables } \\
\hline SPH dummy (\%) (1 if poor health) & & & & & & & & & & \\
\hline & Poor & 29.2 & 43.5 & $<0.001 \&$ & 35.1 & 52.2 & $<0.001 \&$ & 23.4 & 31.4 & $<0.001^{8}$ \\
\hline & Good & 70.8 & 56.5 & & 64.9 & 47.8 & & 76.6 & 68.6 & \\
\hline \multicolumn{2}{|c|}{ SPH discrete, mean (SD) (from 1 "very good" to 5 "very bad") } & $2.9(1.1)$ & $3.3(1.1)$ & $<0.0011^{\circledR}$ & $3.0(1.1)$ & $3.5(1.0)$ & $<0.001{ }^{\circledR}$ & $2.8(1.0)$ & $3.0(1.0)$ & $<0.001^{\mathbb{C}}$ \\
\hline \multicolumn{2}{|l|}{ Objective health status (OHS), mean (SD) } & $0.07(0.1)$ & $0.11(0.1)$ & $<0.001{ }^{\circledR}$ & $0.08(0.1)$ & $0.12(0.2)$ & $<0.001{ }^{\circledR}$ & $0.07(0.1)$ & $0.09(0.1)$ & $<0.001{ }^{\complement}$ \\
\hline \multicolumn{2}{|l|}{ Future health risk (FHR), mean (SD) } & $0.25(0.5)$ & $0.33(0.7)$ & $<0.0011^{\circledR}$ & $0.25(0.5)$ & $0.32(0.6)$ & $<0.001{ }^{\circledR}$ & $0.24(0.6)$ & $0.33(0.8)$ & $<0.001^{\oplus}$ \\
\hline \multicolumn{11}{|l|}{ Demographic variables } \\
\hline \multicolumn{2}{|l|}{ Age, mean (SD) } & $64.1(8.0)$ & $69.9(9.5)$ & $<0.0011^{\circledR}$ & $64.5(8.0)$ & $69.9(9.4)$ & $<0.001{ }^{\circledR}$ & $63.8(8.0)$ & $69.8(9.7)$ & $<0.001^{\Phi}$ \\
\hline Age (\%) & $\begin{array}{l}50 \leq \text { age }<65 \\
\geq 65\end{array}$ & $\begin{array}{l}59.2 \\
40.8\end{array}$ & $\begin{array}{l}32.6 \\
67.4\end{array}$ & $<0.001 \&$ & $\begin{array}{l}57.3 \\
42.7\end{array}$ & $\begin{array}{l}32.3 \\
67.7\end{array}$ & $<0.001$ & $\begin{array}{l}61.1 \\
38.9\end{array}$ & $\begin{array}{l}33 \\
67\end{array}$ & $<0.001^{8}$ \\
\hline Education (\%) & $\begin{array}{l}\text { Lower } \\
\text { Higher }\end{array}$ & $\begin{array}{l}31 \\
69 \\
\end{array}$ & $\begin{array}{l}43.7 \\
56.3\end{array}$ & $<0.001$ \& & $\begin{array}{l}28 \\
72\end{array}$ & $\begin{array}{l}44.4 \\
55.6\end{array}$ & $<0.001$ \& & $\begin{array}{l}33.9 \\
66.1\end{array}$ & $\begin{array}{l}42.9 \\
57.1\end{array}$ & $<0.001^{8}$ \\
\hline \multicolumn{11}{|l|}{ Marital status (\%) } \\
\hline & Married & 73.4 & 61.5 & $<0.001 \&$ & 76.6 & 62.3 & $<0.001 \&$ & 70.2 & 60.4 & $<0.001^{8}$ \\
\hline & Divorced & 11.8 & 12.1 & & 9.6 & 10.8 & & 13.9 & 13.8 & \\
\hline & Widowed & 8.9 & 18.8 & & 9 & 20.1 & & 8.8 & 17 & \\
\hline & Never married & 5.9 & 7.6 & & 4.9 & 6.7 & & 7 & 8.7 & \\
\hline \multicolumn{2}{|l|}{ With children (\%) } & 91.3 & 88.8 & $<0.001$ \& & 93.5 & 90.7 & $<0.001$ \& & 89.1 & 86.3 & $<0.001^{8}$ \\
\hline \multicolumn{2}{|l|}{ Household size, mean (SD) } & $2.3(1.0)$ & $2.0(1.0)$ & $<0.001^{\circledR}$ & $2.4(1.1)$ & $2.1(1.1)$ & $<0.0011^{\circledR}$ & $2.2(1.0)$ & $1.9(0.9)$ & $<0.001^{\oplus}$ \\
\hline \multicolumn{2}{|l|}{ Household income per capita, mean (SD) } & $0.210(0.35)$ & $0.185(0.337)$ & $<0.001^{\circledR}$ & $0.143(0.170)$ & $0.132(0.21)$ & $0.004^{\circledR}$ & $0.276(0.450)$ & $0.260(0.447)$ & $0.060^{\circledR}$ \\
\hline \multicolumn{2}{|l|}{ Net wealth per capita, mean (SD) } & $1.454(3.36)$ & $1.098(3.608)$ & $<0.0011^{\circledR}$ & $1.202(4.15)$ & $0.821(4.13)$ & $<0.001{ }^{\circledR}$ & $1.703(2.303)$ & $1.486(2.661)$ & $<0.001^{\Phi}$ \\
\hline \multicolumn{2}{|l|}{ Pension, mean (SD) } & $0.054(0.133)$ & $0.074(0.159)$ & $<0.0011^{\circledR}$ & $0.040(0.092)$ & $0.049(0.086)$ & $<0.001{ }^{\circledR}$ & $0.067(0.162)$ & $0.108(0.219)$ & $<0.001^{\mathrm{e}}$ \\
\hline \multicolumn{2}{|l|}{ Future retirement age, mean (SD) } & $65.3(3.04)$ & $65.7(2.88)$ & $<0.001{ }^{\circledR}$ & $65.3(3.82)$ & $65.9(3.35)$ & $<0.001{ }^{\circledR}$ & $65.4(1.98)$ & $65.3(0.01)$ & $<0.001^{\Phi}$ \\
\hline \multicolumn{2}{|l|}{ Gross pension replacement rate, mean (SD) } & $58.2(18.0)$ & $59.4(17.3)$ & $<0.0011^{\circledR}$ & $54.6(16.7)$ & $58.3(3.02)$ & $<0.0011^{\circledR}$ & $61.8(18.5)$ & $61.0(18.5)$ & $<0.001^{\complement}$ \\
\hline \multicolumn{2}{|l|}{ Health spending from coverage, mean (SD) } & $0.484(0.620)$ & $0.529(0.647)$ & $<0.001^{\circledR}$ & $0.740(0.763)$ & $0.801(0.785)$ & $<0.001$ @ & $0.226(0.270)$ & $0.333(0.431)$ & $<0.001^{\oplus}$ \\
\hline \multicolumn{2}{|l|}{ Out-of-pocket health spending, mean (SD) } & $0.141(0.170)$ & $0.158(0.179)$ & $<0.0011^{\circledR}$ & $0.215(0.198)$ & $0.238(0.205)$ & $<0.001{ }^{\circledR}$ & $0.067(0.086)$ & $0.101(0.131)$ & $<0.001^{\oplus}$ \\
\hline \multicolumn{2}{|l|}{ Prob. of receiving inheritance, mean (SD) } & $22.0(34.4)$ & $11.5(26.7)$ & $<0.0011^{\circledR}$ & $18.4(32.7)$ & $8.8(23.5)$ & $<0.001{ }^{\circledR}$ & $25.6(35.6)$ & $15.3(30.2)$ & $<0.001^{\Phi}$ \\
\hline \multicolumn{2}{|l|}{ Higher life expectancy $(\%)$} & 81.2 & 69.7 & $<0.001$ \& & 76.5 & 64.7 & $<0.001$ & $\begin{array}{ll}85.8 \\
\end{array}$ & 76.5 & $<0.001^{8}$ \\
\hline \multicolumn{2}{|l|}{ Socially active $(\%)$} & 39.4 & 27.1 & $<0.001$ \& & 35 & 20.8 & $<0.001$ & 43.6 & 35.9 & $<0.001^{8}$ \\
\hline \multicolumn{2}{|l|}{ Religious participation $(\%)$} & 14.5 & 13.1 & $0.003 \&$ & 15.2 & 12 & $<0.001$ & 13.8 & 14.6 & 0.20 \& \\
\hline
\end{tabular}

Note: The dummy SPH variable refers to SPH $=1$ if poor health (indicating level 3, 4, or 5) and SPH $=0$ if good health (indicating level 1 for very good or 2 for good). The discrete SPH variable is measured on a scale of 1 to 5 (1. Very Good, 2. Good, 3. Fair, 4. Bad, 5. Very Bad). OHS variable is a determinant of current overall health as this variable not only considers SPH status but also the numbers of chronic diseases. FHR is evaluated by the increasing function of the average number of risky behaviors (smoking, drinking, and a sedentary lifestyle), the household's Asymptomatic Objective Health Status (measured as the average number of diseases, blood pressure, blood cholesterol, and osteoporosis), and decreasing function of average household grip strength. \& Chi-Square Test; ${ }^{\circledR} t$-test. Monetary amounts are PPP-adjusted and in thousand Euros. Household income per capita, Net wealth per capita, Pension, Health spending from coverage, and Out-of-pocket spending are transferred via natural logarithm. Source: the SHARE data and OECD. Stat (https://stats.oecd.org/Index.aspx). 
To examine the strength of association for life insurance purchase and explanatory variables, we calculate Pearson's correlation. The results are shown in Table A2. There is significantly negative association between life insurance holdings and the three health status variables.

\subsection{The Whole Sample}

Table 2 reports the marginal effects of the variables of interest on the decision to hold life insurance for the whole sample. We first examine the marginal effects of each health status indicator (SPH, OHS, or FHR) separately on the decision to hold life insurance and then examine all three health status indicators simultaneously. For simplification, we only display the estimation results of model including three health status indicators simultaneously in Table 2. The estimation results for each health status indicator (SPH, OHS, or FHR) are provided in Appendix A Table A3.

In Table 2, when we consider all three health status variables simultaneously, the marginal effects of SPH and FHR decrease the probability of purchasing life insurance by $2.1 \%$ and $1.2 \%$, respectively. It is important to note that SPH is the most influential factor among the three variables in the decision to hold life insurance.

Younger households $(50 \leq$ age $<65)$ are more likely to hold life insurance. The marginal effects of age over 65 decrease the probabilities of purchasing life insurance by $12.7 \%$. Our results confirm that the marginal effects of higher educational level increase the probabilities of owning life insurance by $2.2 \%$.

In addition, compared with households in which respondents are divorced or widowed, married households are more likely to hold life insurance, consistent among all three health status variables. We also find that households with children have a higher propensity to hold life insurance the probabilities of purchasing life insurance increase by $2.8 \%$, respectively. Moreover, the probability of holding life insurance increases with both income and net wealth. In addition, the probabilities of receiving inheritance and higher life expectancy ( $50 \%$ or higher) are associated with higher probabilities of owning life insurance.

Furthermore, household pension income is significantly and negatively associated with the decision to buy life insurance and households that are more socially active and possess religious beliefs are more inclined to purchase life insurance. Health spending from coverage (out-of-pocket health spending) is significantly and positively (negatively) associated with the decision to purchasing life insurance, indicating that households are more likely to hold life insurance when there is more (less) health spending from government or compulsory scheme (voluntary schemes or household out-of-pocket payments). In addition, for the impact of national pension system, our results show that future retirement age has a negative and significant association, whereas gross pension replacement rate has positive and significant association, with life insurance holding. Finally, people in advanced countries are more inclined to own life insurance, when compared with those in emerging countries.

\subsection{Analysis for Interaction Effects}

The second column in Table 2 presents the results for the interaction terms among the three health status indicators and non-NHS countries. Unhealthy households (in terms of bad perceived health or poor objective health status) are less likely to own life insurance, except those with higher SPH located in non-NHS countries. This indicates that those households with poor self-perceived health status are more likely purchase life insurance in non-NHS countries than in NHS countries. 
Table 2. Probit regression of purchasing life insurance by whole sample, Age 50+.

\begin{tabular}{|c|c|c|}
\hline \multirow{2}{*}{ Dep. var.: Life Insurance Holding } & \multicolumn{2}{|c|}{ The Whole Sample $(\mathrm{N}=34,341)$} \\
\hline & Model 1 & Model 2 \\
\hline SPH dummy & $\begin{array}{c}-0.0205^{* * *} \\
(0.005)\end{array}$ & $\begin{array}{c}-0.0346^{* * *} \\
(0.006)\end{array}$ \\
\hline OHS & $\begin{array}{c}0.00152 \\
(0.018)\end{array}$ & $\begin{array}{c}-0.0162 \\
(0.023)\end{array}$ \\
\hline FHR & $\begin{array}{c}-0.0121^{* * *} \\
(0.004)\end{array}$ & $\begin{array}{c}-0.0100 * \\
(0.006)\end{array}$ \\
\hline \multicolumn{3}{|l|}{ Demographic variables } \\
\hline Age $\geq 65$ & $\begin{array}{c}-0.127^{* * *} \\
(0.007)\end{array}$ & $\begin{array}{c}-0.124^{* * *} \\
(0.007)\end{array}$ \\
\hline Higher education & $\begin{array}{c}0.0216^{* * *} \\
(0.005)\end{array}$ & $\begin{array}{c}0.0190 * * * \\
(0.005)\end{array}$ \\
\hline \multicolumn{3}{|l|}{ Marital status (ref: Never married) } \\
\hline Married & $\begin{array}{c}0.0566^{* * *} \\
(0.009)\end{array}$ & $\begin{array}{c}0.0564^{* * *} \\
(0.009)\end{array}$ \\
\hline Divorced & $\begin{array}{l}0.0142 \\
(0.010)\end{array}$ & $\begin{array}{l}0.0133 \\
(0.010) \\
\end{array}$ \\
\hline Widowed & $\begin{array}{c}-0.00574 \\
(0.010)\end{array}$ & $\begin{array}{c}-0.00729 \\
(0.010)\end{array}$ \\
\hline With children & $\begin{array}{c}0.0281^{* * *} \\
(0.008)\end{array}$ & $\begin{array}{c}0.0286^{* * *} \\
(0.008)\end{array}$ \\
\hline Household income per capita & $\begin{array}{c}0.0225 * * * \\
(0.003)\end{array}$ & $\begin{array}{c}0.0230 * * * \\
(0.003)\end{array}$ \\
\hline Household income per capita squared & $\begin{array}{c}0.000 \\
(0.000)\end{array}$ & $\begin{array}{c}0.000 \\
(0.000)\end{array}$ \\
\hline Net wealth per capita & $\begin{array}{c}0.0148^{* * *} \\
(0.001)\end{array}$ & $\begin{array}{c}0.0151^{* * *} \\
(0.001)\end{array}$ \\
\hline Net wealth per capita squared & $\begin{array}{c}0.000 \\
(0.000)\end{array}$ & $\begin{array}{c}0.000 \\
(0.000)\end{array}$ \\
\hline Prob. of receiving inheritance & $\begin{array}{c}0.000630 \\
(0.000)\end{array}$ & $\begin{array}{c}0.000649^{* * * *} \\
(0.000)\end{array}$ \\
\hline Pension & $\begin{array}{c}-0.00423^{* * *} \\
(0.001)\end{array}$ & $\begin{array}{c}-0.00449 \text { *** } \\
(0.001)\end{array}$ \\
\hline Future retirement age & $\begin{array}{c}-0.0166^{* * *} \\
(0.001)\end{array}$ & $\begin{array}{c}-0.0154 * * * \\
(0.001)\end{array}$ \\
\hline Gross pension replacement rate & $\begin{array}{c}0.000484^{* *} \\
(0.000)\end{array}$ & $\begin{array}{c}0.000579^{* * *} \\
(0.000)\end{array}$ \\
\hline Health spending from coverage & $\begin{array}{c}0.0907^{* * *} \\
(0.007)\end{array}$ & $\begin{array}{c}0.0859 * * * \\
(0.007)\end{array}$ \\
\hline Out-of-pocket health spending & $\begin{array}{c}-0.0938^{* * *} \\
(0.008)\end{array}$ & $\begin{array}{c}-0.0870^{* * *} \\
(0.008)\end{array}$ \\
\hline Higher Life expectancy & $\begin{array}{c}0.0370 * * * \\
(0.005)\end{array}$ & $\begin{array}{c}0.0378^{* * *} \\
(0.005)\end{array}$ \\
\hline Social activity & $\begin{array}{c}0.0401 * * * \\
(0.005)\end{array}$ & $\begin{array}{c}0.0400 \text { *** } \\
(0.005)\end{array}$ \\
\hline Religious participation & $\begin{array}{c}0.0276^{* * *} \\
(0.006)\end{array}$ & $\begin{array}{c}0.0276^{* * *} \\
(0.006)\end{array}$ \\
\hline
\end{tabular}


Table 2. Cont.

\begin{tabular}{lcc}
\hline \multirow{2}{*}{ Dep. var.: Life Insurance Holding } & \multicolumn{2}{c}{ The Whole Sample (N = 34,341) } \\
\cline { 2 - 3 } & Model 1 & Model 2 \\
\hline Advanced (ref: Emerging) & $\begin{array}{c}0.0275^{* * *} \\
(0.008)\end{array}$ \\
\hline Non-NHS (ref: NHS) & 0.00235 \\
& & $(0.006)$ \\
\hline SPH dummy $\times$ Non-NHS & $0.0327^{* * *}$ \\
& & $(0.008)$ \\
\hline OHS $\times$ Non-NHS & 0.044 \\
& & $(0.035)$ \\
\hline FHR $\times$ Non-NHS & 0.004 \\
\hline Pseudo R ${ }^{2}$ & 0.101 & $(0.007)$ \\
\hline Log likelihood & $-15,842.956$ & 0.102 \\
\hline Not & & $-15,852.956$ \\
\hline
\end{tabular}

Note: This table reports mean marginal effects evaluated at each observation. Monetary amounts are PPP-adjusted and in thousand Euros. The dummy SPH variable refers to $\mathrm{SPH}=1$ if poor health (indicating level 3,4 or 5) and $\mathrm{SPH}=0$ if good health (indicating level 1 for very good, 2 for good). OHS variable is the determinant of current overall health as this variable not only considers the SPH status but also the numbers of chronic diseases. FHR evaluates the increasing function of the average number of risky behaviors (smoking, drinking, and a sedentary lifestyle), the household's Asymptomatic Objective Health Status (measured as the average number of diseases, blood pressure, blood cholesterol and osteoporosis), and decreasing function of average household grip strength. Standard errors in parentheses, ${ }^{* * *} p<0.01,{ }^{* *} p<0.05, * p<0.1$. Source: the SHARE data and OECD.Stat (https://stats.oecd.org/Index.aspx).

\subsection{NHS versus Non-NHS Countries}

We next investigate whether NHS impacts on the relation between health status and life insurance holdings, by analyzing the data of the two subgroups: NHS versus non-NHS countries. We follow the same MNL model to observe whether there is significant impact by any explanatory variable on the dependent variable in the whole sample.

Table 3 shows that the estimated marginal effects are different from the results of the whole sample. When considering all three health status indicators together, we find that SPH and FHR health status variables are significantly and negatively associated with life insurance only in NHS countries ( $2.7 \%$ and $0.9 \%$, respectively). The estimation results for each health status indicator (SPH, OHS, or FHR) are provided in Table A4 displayed in the Appendix A. However, only FHR has a significant influence on the decision to purchase life insurance (1.7\% decrease) for non-NHS countries.

Table 3. Probit regression of purchasing life insurance by different NHS, Age 50+.

\begin{tabular}{lcc}
\hline Dep. var.: Binary for Holding Life Insurance & Non-NHS $\mathbf{N}=\mathbf{1 4}, \mathbf{9 5 8})$ & NHS $\mathbf{( N = 1 9 , 3 8 3 )}$ \\
\hline SPH dummy & -0.0038 & $-0.0267^{* * *}$ \\
& $(0.008)$ & $(0.006)$ \\
\hline OHS & 0.0406 & -0.0179 \\
& $(0.031)$ & $(0.021)$ \\
\hline FHR & $-0.0166^{* * *}$ & $-0.00868^{*}$ \\
& $(0.005)$ & $(0.005)$ \\
\hline Demographic variables & & $-0.0911^{* * *}$ \\
\hline Age $\geq 65$ & $-0.152^{* * *}$ & $(0.008)$ \\
\hline Higher education & $(0.011)$ & $0.0238^{* * *}$ \\
& $0.0126^{*}$ & $(0.006)$ \\
\hline
\end{tabular}


Table 3. Cont.

\begin{tabular}{|c|c|c|}
\hline Dep. var.: Binary for Holding Life Insurance & Non-NHS $(\mathrm{N}=14,958)$ & NHS $(\mathrm{N}=19,383)$ \\
\hline \multicolumn{3}{|l|}{ Marital status (ref: Never married) } \\
\hline Married & $\begin{array}{c}0.0532 * * * \\
(0.014)\end{array}$ & $\begin{array}{c}0.0529 * * * \\
(0.012)\end{array}$ \\
\hline Divorced & $\begin{array}{l}0.0212 \\
(0.016)\end{array}$ & $\begin{array}{c}-0.0016 \\
(0.014)\end{array}$ \\
\hline Widowed & $\begin{array}{c}-0.00777 \\
(0.016)\end{array}$ & $\begin{array}{c}-0.0144 \\
(0.013)\end{array}$ \\
\hline With children & $\begin{array}{c}0.0299 * * * \\
(0.011)\end{array}$ & $\begin{array}{c}0.0304^{* * *} \\
(0.011)\end{array}$ \\
\hline Income per capita & $\begin{array}{c}0.0174^{* * *} \\
(0.004)\end{array}$ & $\begin{array}{c}0.0289 * * * \\
(0.003)\end{array}$ \\
\hline Income per capita squared & $\begin{array}{c}0.000 \\
(0.000)\end{array}$ & $\begin{array}{c}0.000 \\
(0.000)\end{array}$ \\
\hline Net wealth per capita & $\begin{array}{c}0.0184^{* * *} \\
(0.001)\end{array}$ & $\begin{array}{c}0.0161^{* * *} \\
(0.001)\end{array}$ \\
\hline Net wealth per capita squared & $\begin{array}{c}0.000 \\
(0.000)\end{array}$ & $\begin{array}{c}0.000 \\
(0.000)\end{array}$ \\
\hline Prob. of receiving inheritance & $\begin{array}{c}0.000543^{* * *} \\
(0.000)\end{array}$ & $\begin{array}{c}0.0008911^{* * *} \\
(0.000)\end{array}$ \\
\hline Pension & $\begin{array}{c}-0.00552^{* * *} \\
(0.001)\end{array}$ & $\begin{array}{c}-0.00456^{* * *} \\
(0.001)\end{array}$ \\
\hline Future retirement age & $\begin{array}{c}-0.0202 * * * \\
(0.003)\end{array}$ & $\begin{array}{c}0.00498^{* * * *} \\
(0.002)\end{array}$ \\
\hline Gross pension replacement rate & $\begin{array}{c}0.00143^{* * *} \\
(0.000)\end{array}$ & $\begin{array}{c}-0.00500 * * * \\
(0.000)\end{array}$ \\
\hline Health spending from coverage & $\begin{array}{l}0.116^{* * *} \\
(0.014)\end{array}$ & $\begin{array}{c}0.00702 \\
(0.011)\end{array}$ \\
\hline Out-of-pocket health spending & $\begin{array}{c}-0.154^{* * *} \\
(0.015)\end{array}$ & $\begin{array}{l}0.0152 \\
(0.011)\end{array}$ \\
\hline Higher Life expectancy & $\begin{array}{c}0.0449 * * * \\
(0.009)\end{array}$ & $\begin{array}{c}0.0348^{* * *} \\
(0.006)\end{array}$ \\
\hline Social activity & $\begin{array}{c}0.0269^{* * *} \\
(0.007)\end{array}$ & $\begin{array}{c}0.0644^{* * *} \\
(0.007)\end{array}$ \\
\hline Religious participation & $\begin{array}{c}-0.0156^{*} \\
(0.009)\end{array}$ & $\begin{array}{c}0.0328 * * * \\
(0.008)\end{array}$ \\
\hline Pseudo $\mathrm{R}^{2}$ & 0.093 & 0.123 \\
\hline Log likelihood & -7510.732 & -8133.964 \\
\hline
\end{tabular}

Note: Mean marginal effects evaluated at each observation. Monetary amounts are PPP-adjusted and in thousand Euros. The dummy SPH variable refers to SPH $=1$ if poor health (indicating level 3, 4, or 5) and SPH $=0$ if good health (indicating level 1 for very good, 2 for good). OHS variable is the determinant of current overall health as this variable not only considers the SPH status but also the numbers of chronic diseases. FHR evaluates the increasing function of the average number of risky behaviors (smoking, drinking, and a sedentary lifestyle), the household's Asymptomatic Objective Health Status (measured as the average number of diseases, blood pressure, blood cholesterol, and osteoporosis), and decreasing function of average household grip strength. Standard errors in parentheses, ${ }^{* * *} p<0.01,{ }^{*} p<0.1$ Source: the SHARE data and OECD.Stat (https://stats.oecd.org/Index.aspx).

The results of the other explanatory variables in NHS countries are comparable with the findings of the whole sample, except for pension. In contrast, our empirical findings related to the relationship between religion and life insurance demand are unclear in non-NHS countries.

We investigate the interaction effects, focusing on those among the three health status variables and two demographic variables of older age (Age $\geq 65)$ and higher level of education, following Atella et al. [7]. This study highlights the impact of age on household decisions to hold risky assets. The primary intention is to examine those interactions and whether there are differences in health 
factors depending on if the person in the household deciding on life insurance purchase is elderly or highly educated.

Table 4 illustrates that there is no significant result for the interaction terms among the three health status variables and the higher level of education. We further test the interaction effects of health status with old age (Age $\geq 65$ ) on the probability of owning life insurance in the whole sample and in the two subsamples, NHS and non-NHS countries, separately, shown in Table 5. Interestingly, the marginal effects of the interaction between FHR and Age $\geq 65$ on life insurance are strongly (1\%) significant for both whole sample and in the subsample of non-NHS countries when considering the health status variables together. We present the estimation results by considering each health status individually, provided in Appendix A Table A6. This implies that elderly households with high probability of future risk tend to purchase life insurance. However, it is very difficult for insurers to distinguish among the types of health situations that insured may present with in the future.

Table 4. Interaction terms with three health status indicators and higher education, whole sample, NHS countries, and Non-NHS countries, Age 50+.

\begin{tabular}{|c|c|c|c|}
\hline Dep. var.: Binary for Holding Life Insurance & $\begin{array}{l}\text { The Whole Sample } \\
\qquad(\mathrm{N}=34,341)\end{array}$ & $\begin{array}{l}\text { Non-NHS } \\
(\mathrm{N}=14,958)\end{array}$ & $\begin{array}{c}\text { NHS } \\
(\mathrm{N}=19,383)\end{array}$ \\
\hline SPH dummy & $\begin{array}{l}-0.0155^{* *} \\
(0.008)\end{array}$ & $\begin{array}{c}0.000457 \\
(0.013)\end{array}$ & $\begin{array}{l}-0.0224 \text { ** } \\
(0.010)\end{array}$ \\
\hline OHS & $\begin{array}{l}0.0106 \\
(0.025)\end{array}$ & $\begin{array}{l}0.0476 \\
(0.043)\end{array}$ & $\begin{array}{c}-0.00458 \\
(0.030)\end{array}$ \\
\hline FHR & $\begin{array}{l}-0.0101 * \\
(0.005)\end{array}$ & $\begin{array}{l}-0.0155^{* *} \\
\quad(0.008)\end{array}$ & $\begin{array}{c}-0.00664 \\
(0.008)\end{array}$ \\
\hline \multicolumn{4}{|l|}{ Demographic variables } \\
\hline Age $\geq 65$ & $\begin{array}{l}-0.127^{* * *} \\
(0.007)\end{array}$ & $\begin{array}{l}-0.152^{* * *} \\
(0.011)\end{array}$ & $\begin{array}{l}-0.0912 * * * \\
\quad(0.008)\end{array}$ \\
\hline Higher education & $\begin{array}{c}0.0273^{* * *} \\
(0.006)\end{array}$ & $\begin{array}{l}0.0165^{*} \\
(0.009)\end{array}$ & $\begin{array}{c}0.0304^{* * *} \\
(0.008)\end{array}$ \\
\hline SPH dummy $\times$ Higher education & $\begin{array}{c}-0.00795 \\
(0.010)\end{array}$ & $\begin{array}{l}-0.00723 \\
(0.017)\end{array}$ & $\begin{array}{c}-0.00634 \\
(0.012)\end{array}$ \\
\hline OHS $\times$ Higher education & $\begin{array}{c}-0.0185 \\
(0.035)\end{array}$ & $\begin{array}{c}-0.0141 \\
(0.060)\end{array}$ & $\begin{array}{c}-0.0263 \\
(0.041)\end{array}$ \\
\hline FHR $\times$ Higher education & $\begin{array}{c}-0.00366 \\
(0.007)\end{array}$ & $\begin{array}{c}-0.0023 \\
(0.011)\end{array}$ & $\begin{array}{c}-0.00369 \\
(0.010)\end{array}$ \\
\hline Other controls & \multicolumn{3}{|c|}{$\begin{array}{l}\text { Marital status, with child, Household income per capita, } \\
\text { Household income per capita squared, Net wealth per } \\
\text { capita, Net wealth per capita squared, Probability of } \\
\text { receiving inheritance, Pension, Future retirement age, Gross } \\
\text { pension replacement rate, Health spending from coverage, } \\
\text { Out-of-pocket health spending, Higher life expectancy, } \\
\text { Social activity, Religious participation, and Country dummy }\end{array}$} \\
\hline Pseudo $R^{2}$ & 0.101 & 0.093 & 0.124 \\
\hline Log likelihood & $-15,858.79$ & -7510.494 & -8133.286 \\
\hline
\end{tabular}

Note: Means of marginal effects evaluated at each observation. Monetary amounts are PPP-adjusted and in thousand Euros. The dummy SPH variable refers to $\mathrm{SPH}=1$ if poor health (indicating level 3,4 , or 5) and $\mathrm{SPH}=0$ if good health (indicating level 1 for very good, 2 good). OHS variable is the determinant of current overall health as this variable not only considers the SPH status but also the numbers of chronic diseases. FHR evaluates the increasing function of the average number of risky behaviors (smoking, drinking, and a sedentary lifestyle), the household's Asymptomatic Objective Health Status (measured as the average number of diseases, blood pressure, blood cholesterol, and osteoporosis), and decreasing function of average household grip strength. Standard errors in parentheses, ${ }^{* * *} p<0.01,{ }^{* *} p<0.05,{ }^{*} p<0.1$. Source: the SHARE data and OECD. Stat (https://stats.oecd.org/Index.aspx). 
Table 5. Interaction terms with three health status indicators and age $\geq 65$, whole sample, NHS countries, and Non-NHS countries, Age 50+.

\begin{tabular}{|c|c|c|c|}
\hline Dep. var.: Binary for Holding Life Insurance & $\begin{array}{l}\text { The Whole Sample } \\
\qquad(\mathrm{N}=34,341)\end{array}$ & $\begin{array}{l}\text { Non-NHS } \\
(\mathrm{N}=14958)\end{array}$ & $\begin{array}{c}\text { NHS } \\
(\mathrm{N}=19383)\end{array}$ \\
\hline SPH dummy & $\begin{array}{c}-0.0211^{* * *} \\
(0.007)\end{array}$ & $\begin{array}{c}-0.00878 \\
(0.013)\end{array}$ & $\begin{array}{c}-0.0190^{* *} \\
(0.009)\end{array}$ \\
\hline OHS & $\begin{array}{l}0.0204 \\
(0.032)\end{array}$ & $\begin{array}{l}0.0285 \\
(0.056)\end{array}$ & $\begin{array}{l}0.0118 \\
(0.037)\end{array}$ \\
\hline FHR & $\begin{array}{l}-0.0243^{* * *} \\
(0.007)\end{array}$ & $\begin{array}{c}-0.0367^{* * *} \\
(0.010)\end{array}$ & $\begin{array}{c}-0.0121 \\
(0.009)\end{array}$ \\
\hline \multicolumn{4}{|l|}{ Demographic variables } \\
\hline Age $\geq 65$ & $\begin{array}{l}-0.130^{* * *} \\
(0.008)\end{array}$ & $\begin{array}{l}-0.165^{* * * *} \\
(0.012)\end{array}$ & $\begin{array}{c}-0.0822 * * * \\
(0.010)\end{array}$ \\
\hline Higher education & $\begin{array}{l}0.0217^{* * *} \\
(0.005)\end{array}$ & $\begin{array}{l}0.0127^{*} \\
(0.007)\end{array}$ & $\begin{array}{c}0.0237^{* * *} \\
(0.006)\end{array}$ \\
\hline SPH poor $\times$ Age $\geq 65$ & $\begin{array}{l}0.00113 \\
(0.010)\end{array}$ & $\begin{array}{c}0.00949 \\
(0.017) \\
\end{array}$ & $\begin{array}{c}-0.0146 \\
(0.012)\end{array}$ \\
\hline OHS $\times$ Age $\geq 65$ & $\begin{array}{c}-0.0277 \\
(0.038)\end{array}$ & $\begin{array}{l}0.0111 \\
(0.067)\end{array}$ & $\begin{array}{c}-0.0408 \\
(0.045)\end{array}$ \\
\hline FHR $\times$ Age $\geq 65$ & $\begin{array}{l}0.0178^{* *} \\
(0.008)\end{array}$ & $\begin{array}{l}0.0297^{* * *} \\
(0.012)\end{array}$ & $\begin{array}{l}0.00487 \\
(0.011)\end{array}$ \\
\hline Other controls & \multicolumn{3}{|c|}{$\begin{array}{l}\text { Marital status, with child, Household income per capita, } \\
\text { Household income per capita squared, Net wealth per } \\
\text { capita, Net wealth per capita squared, Probability of } \\
\text { receiving inheritance, Pension, Future retirement age, Gross } \\
\text { pension replacement rate, Health spending from coverage, } \\
\text { Out-of-pocket health spending, Higher life expectancy, } \\
\text { Social activity, Religious participation, and Country dummy }\end{array}$} \\
\hline Pseudo $R^{2}$ & 0.101 & 0.094 & 0.124 \\
\hline Log likelihood & $-15,857.09$ & -7506.71 & -8132.09 \\
\hline
\end{tabular}

Note: Means of marginal effects evaluated at each observation. Monetary amounts are PPP-adjusted and in thousand Euros. The dummy SPH variable refers to $\mathrm{SPH}=1$ if poor health (indicating level 3, 4, or 5) and $\mathrm{SPH}=0$ if good health (indicating level 1 for very good, 2 good). OHS variable is the determinant of current overall health as this variable not only considers the SPH status but also the numbers of chronic diseases. FHR evaluates the increasing function of the average number of risky behaviors (smoking, drinking, and a sedentary lifestyle), the household's Asymptomatic Objective Health Status (measured as the average number of diseases, blood pressure, blood cholesterol, and osteoporosis), and decreasing function of average household grip strength. Standard errors in parentheses, ${ }^{* * *} p<0.01, * * p<0.05, * p<0.1$. Source: the SHARE data and OECD.Stat (https://stats.oecd.org/Index.aspx).

\subsection{Marginal Effect of the Preference for Type of Life Insurance}

The marginal effects of each of the three health status variables on the probability of holding different types of insurance are estimated for the whole sample, including term life insurance, whole life insurance, both (term life and whole life insurance) policies, and no life insurance. When we consider only OHS indicator in our regression model, our results show that OHS is only significantly and negatively related to both types of life insurance, the estimation results are shown in Table A7 exhibited in the Appendix A. When considering all three health status variables, shown in Table 6, the results reveal that households with poor SPH or high FHR risk are less likely to hold only term life or both types of life insurance. It seems that poor health statuses (for SPH and FHR indicators) are not supportive of holding only term life insurance. A possible explanation is that term life policy is associated with relatively lower premiums compared to whole life policy and insurers have stricter underwriting process in terms of evaluating the health condition of the insured. Thus, households with poor health status are less likely to buy a term life policy. In contrast, those with no life insurance have lower SPH and higher FHR. However, we do not find any significant evidence for the relationship between the decision to own only whole life insurance and health status. 
Table 6. Marginal effects of purchasing different types of life insurance, whole sample, $\mathrm{N}=34,341$, Age 50+.

\begin{tabular}{|c|c|c|c|c|}
\hline Dep. var.: Binary for Holding Life Insurance & Term & Whole & Both & No LI * \\
\hline SPH dummy & $\begin{array}{c}-0.00700 * * * \\
(0.003)\end{array}$ & $\begin{array}{l}0.00228 \\
(0.004)\end{array}$ & $\begin{array}{c}-0.0169 * * * \\
(0.004)\end{array}$ & $\begin{array}{c}0.0217^{* * *} \\
(0.005)\end{array}$ \\
\hline OHS & $\begin{array}{l}0.0133 \\
(0.009)\end{array}$ & $\begin{array}{c}-0.00313 \\
(0.013)\end{array}$ & $\begin{array}{c}-0.00454 \\
(0.013)\end{array}$ & $\begin{array}{c}-0.00561 \\
(0.018)\end{array}$ \\
\hline FHR & $\begin{array}{c}-0.00565^{* * *} \\
(0.002)\end{array}$ & $\begin{array}{c}0.000574 \\
(0.003)\end{array}$ & $\begin{array}{c}-0.00887^{* * *} \\
(0.003)\end{array}$ & $\begin{array}{c}0.0139 * * * \\
(0.004)\end{array}$ \\
\hline \multicolumn{5}{|l|}{ Demographic variables } \\
\hline Age $\geq 65$ & $\begin{array}{c}-0.0328^{* * *} \\
(0.003)\end{array}$ & $\begin{array}{c}-0.0343^{* * *} \\
(0.005)\end{array}$ & $\begin{array}{c}-0.0579 * * * \\
(0.005)\end{array}$ & $\begin{array}{c}0.125^{* * *} \\
(0.007)\end{array}$ \\
\hline Higher education & $\begin{array}{c}0.00514^{* *} \\
(0.002)\end{array}$ & $\begin{array}{c}0.0114^{* * *} \\
(0.003)\end{array}$ & $\begin{array}{c}0.00663 \text { ** } \\
(0.003)\end{array}$ & $\begin{array}{c}-0.0232 * * * \\
(0.005)\end{array}$ \\
\hline \multicolumn{5}{|l|}{ Marital status (ref: Never married) } \\
\hline Married & $\begin{array}{c}0.00913^{* *} \\
(0.004)\end{array}$ & $\begin{array}{c}0.0324^{* * *} \\
(0.006)\end{array}$ & $\begin{array}{c}0.0161^{* *} \\
(0.007)\end{array}$ & $\begin{array}{c}-0.0576^{* * *} \\
(0.009)\end{array}$ \\
\hline Divorced & $\begin{array}{c}0.0107^{* *} \\
(0.005)\end{array}$ & $\begin{array}{c}0.0148^{* *} \\
(0.007)\end{array}$ & $\begin{array}{c}-0.0115 \\
(0.007)\end{array}$ & $\begin{array}{c}-0.0139 \\
(0.010) \\
\end{array}$ \\
\hline Widowed & $\begin{array}{l}0.0019 \\
(0.005)\end{array}$ & $\begin{array}{l}0.0115^{*} \\
(0.007)\end{array}$ & $\begin{array}{c}-0.0187^{* * *} \\
(0.007)\end{array}$ & $\begin{array}{l}0.00532 \\
(0.010)\end{array}$ \\
\hline With children & $\begin{array}{c}0.00685^{* *} \\
(0.003)\end{array}$ & $\begin{array}{c}-0.00343 \\
(0.006) \\
\end{array}$ & $\begin{array}{c}0.0238^{* * *} \\
(0.005) \\
\end{array}$ & $\begin{array}{c}-0.0272 * * * \\
(0.008)\end{array}$ \\
\hline Income per capita & $\begin{array}{c}0.00570^{* * *} \\
(0.001)\end{array}$ & $\begin{array}{c}0.00521^{* * *} \\
(0.002)\end{array}$ & $\begin{array}{c}0.0101 * * * \\
(0.002)\end{array}$ & $\begin{array}{c}-0.0210^{* * *} \\
(0.003)\end{array}$ \\
\hline Income per capita squared & $\begin{array}{c}0.000 \\
(0.000)\end{array}$ & $\begin{array}{c}0.000 \\
(0.000)\end{array}$ & $\begin{array}{c}0.000 \\
(0.000)\end{array}$ & $\begin{array}{l}0.000 \\
(0.000)\end{array}$ \\
\hline Net wealth per capita & $\begin{array}{c}0.00467^{* * *} \\
(0.001)\end{array}$ & $\begin{array}{c}0.00868 * * * \\
(0.001)\end{array}$ & $\begin{array}{c}0.00234^{* * *} \\
(0.001)\end{array}$ & $\begin{array}{c}-0.0157 * * * \\
(0.001)\end{array}$ \\
\hline Net wealth per capita squared & $\begin{array}{c}0.000 \\
(0.000)\end{array}$ & $\begin{array}{c}0.000 \\
(0.000)\end{array}$ & $\begin{array}{c}0.000 \\
(0.000)\end{array}$ & $\begin{array}{c}0.000 \\
(0.000)\end{array}$ \\
\hline Prob. of receiving inheritance & $\begin{array}{c}0.000136^{* * *} \\
(0.000)\end{array}$ & $\begin{array}{c}0.000285^{* * *} \\
(0.000)\end{array}$ & $\begin{array}{c}0.000235^{* * *} \\
(0.000)\end{array}$ & $\begin{array}{c}-0.000657^{* * *} \\
(0.000)\end{array}$ \\
\hline Pension & $\begin{array}{c}-0.000789^{* * * *} \\
(0.000)\end{array}$ & $\begin{array}{c}-0.00146^{* * *} \\
(0.000)\end{array}$ & $\begin{array}{c}-0.00222 * * * \\
(0.000)\end{array}$ & $\begin{array}{c}0.00447^{* * * *} \\
(0.001)\end{array}$ \\
\hline Future retirement age & $\begin{array}{c}-0.00628 \text { *** } \\
(0.001)\end{array}$ & $\begin{array}{c}-0.00318^{* * *} \\
(0.001)\end{array}$ & $\begin{array}{c}-0.00630^{* * *} \\
(0.001)\end{array}$ & $\begin{array}{c}0.0158^{* * *} \\
(0.001)\end{array}$ \\
\hline Gross pension replacement rate & $\begin{array}{c}0.00149^{* * *} \\
(0.000)\end{array}$ & $\begin{array}{c}-0.000885^{* * *} \\
(0.000)\end{array}$ & $\begin{array}{c}-0.0000854 \\
(0.000)\end{array}$ & $\begin{array}{c}-0.000518^{* * *} \\
(0.000)\end{array}$ \\
\hline Health spending from coverage & $\begin{array}{c}-0.0423^{* * *} \\
(0.004)\end{array}$ & $\begin{array}{c}0.0641^{* * *} \\
(0.005)\end{array}$ & $\begin{array}{c}0.0574^{* * *} \\
(0.005)\end{array}$ & $\begin{array}{c}-0.0792 * * * \\
(0.008)\end{array}$ \\
\hline Out-of-pocket health spending & $\begin{array}{c}0.0267^{* * *} \\
(0.004)\end{array}$ & $\begin{array}{c}-0.0335^{* * * *} \\
(0.005)\end{array}$ & $\begin{array}{c}-0.0781^{* * *} \\
(0.006)\end{array}$ & $\begin{array}{c}0.0850^{* * *} \\
(0.008)\end{array}$ \\
\hline Higher Life expectancy & $\begin{array}{c}0.00634^{* *} \\
(0.003)\end{array}$ & $\begin{array}{c}0.0183^{* * *} \\
(0.003)\end{array}$ & $\begin{array}{c}0.0119^{* * *} \\
(0.003)\end{array}$ & $\begin{array}{c}-0.0365^{* * *} \\
(0.005)\end{array}$ \\
\hline Social activity & $\begin{array}{c}0.0191 * * * \\
(0.002)\end{array}$ & $\begin{array}{c}0.00756^{* *} \\
(0.003)\end{array}$ & $\begin{array}{c}0.0127^{* * *} \\
(0.003)\end{array}$ & $\begin{array}{c}-0.0394 \text { *** } \\
(0.005)\end{array}$ \\
\hline Religious participation & $\begin{array}{c}0.00278 \\
(0.003)\end{array}$ & $\begin{array}{c}0.0185^{* * *} \\
(0.005)\end{array}$ & $\begin{array}{c}0.00329 \\
(0.004)\end{array}$ & $\begin{array}{c}-0.0245^{* * *} \\
(0.006)\end{array}$ \\
\hline Advanced markets (ref: Emerging markets) & $\begin{array}{c}0.0452^{* * *} \\
(0.003)\end{array}$ & $\begin{array}{c}-0.0268^{* * *} \\
(0.006)\end{array}$ & $\begin{array}{c}0.0145^{* * *} \\
(0.005)\end{array}$ & $\begin{array}{c}-0.0330 * * * \\
(0.008)\end{array}$ \\
\hline
\end{tabular}

Note: Mean marginal effects evaluated at each observation. No LI ${ }^{*}$ means households without life insurance. Monetary amounts are PPP-adjusted and in thousand Euros. The dummy SPH variable refers to SPH $=1$ if poor health (indicating level 3, 4, or 5) and SPH $=0$ if good health (indicating level 1 for very good, 2 for good). OHS variable is the determinant of current overall health as this variable not only considers the SPH status but also the numbers of chronic diseases. FHR evaluates the increasing function of the average number of risky behaviors (smoking, drinking, and a sedentary lifestyle), the household's Asymptomatic Objective Health Status (measured as the average number of diseases, blood pressure, blood cholesterol, and osteoporosis), and decreasing function of average household grip strength. Standard errors in parentheses, ${ }^{* * *} p<0.01,{ }^{* *} p<0.05,{ }^{*} p<0.1$. Source: the SHARE data and OECD.Stat (https:/ / stats.oecd.org/Index.aspx). 
Our results show no clear confirmation of the association between any of the three health status variables and whole life insurance holdings. Households without life insurance holdings are more likely to have serious health conditions or risks. Moreover, households with term life insurance only are more likely to be young, highly educated, married, socially active and more religious, with children, higher income and net wealth, higher probability of receiving inheritance, and higher life expectancy. In addition, households with whole life insurance are more likely to have married, divorced, or widowed respondents and young, highly educated, socially active and more religious, higher income and net wealth, higher probability of receiving inheritance, and higher life expectancy. Furthermore, owning both types of life insurance is significantly associated with younger age, married status, with children, higher income and net wealth, higher probability of receiving inheritance, higher life expectancy, and being socially active.

The signs of demographic variables for the households having no life insurance are, in general, the opposite of those for the households purchasing different types of insurance. The characteristics of the households with no life insurance holdings include older age, lower educational level, unmarried status, with fewer children, having less financial possibility but higher pension income, lower probability of receiving inheritance, lower life expectancy, socially inactive and less religious.

\section{Discussion}

To our knowledge, this is the first study that examines the effects of three different health status indicators on the demand for life insurance in European countries. Our findings show that two health status indicators (SPH and FHR) are negatively associated with the decision to hold life insurance in the whole sample, but only in NHS countries on subgroup analysis. Our results are consistent with the findings of Fang and Kung [15], in which healthy individuals are more likely to have life insurance in the US. However, results of subgroup analysis show that only FHR has a decreasing effect on the purchase of life insurance in non-NHS countries.

Consistent with Inkmann and Michaelides [27], we find a negative relationship between age and households owning life insurance. An earlier study by Zeitz [26] did not reveal evidence of an association between educational level and the holding of life insurance. Later on, Ward and Zurbruegg [29] and Li et al. [11] demonstrated that life insurance demand is lower (higher) among households with lower (higher) educational level. Thus, this study provides additional confirmation that educational level is positively associated with life insurance demand. Moreover, consistent with the findings in the literature on the bequest motive $[27,28]$, our results reveal that households with married respondents or with children have a higher propensity to hold life insurance.

In addition, consistent with the literature $[10,11,26]$, our findings also indicate that households with higher income level or higher net wealth have higher life insurance demand. Interestingly, we find that households with religious beliefs are more inclined to hold life insurance. However, this finding differs from those of previous studies on Islamic countries and Muslim communities [9,29,34]. Thus, from the literature and our results, we conclude that the decision to purchase life insurance might depend on particular religious beliefs.

Moreover, our results demonstrate that both SPH and FHR health status indicators are significantly and negatively associated with life insurance holdings in the entire sample as well as in the subsample in NHS countries. However, only FHR has a significantly negative impact on the decision to purchase life insurance in non-NHS countries. Our findings contradict those of Atella et al. [7], in which the relationship between health status variables and risky financial assets holdings are ambiguous in NHS countries, but the holdings of risky financial assets decrease in households, based on SPH and FHR in non-NHS countries. Our findings also differ from those of Bressan et al. [8] who reveal that SPH is significantly and negatively related to direct and indirect stockownership in both NHS and non-NHS countries. The implication of our study is that the decision to hold life insurance or risky assets among households differs from the assessment of financial tools from the risk management point of view. 


\section{Conclusions}

Compared with previous works of other determinants on life insurance ownership based on data from only one country, our study examines household life insurance holdings in 16 European countries and focuses on three health status variables. We also investigate the impact of health status on the purchase of different types of life insurance (term life only, whole life only, or both types) and characteristics of the health care system in the countries of residence. In all cases, we include a set of standard socio-economic and demographic variables as control variables. Our whole sample is classified into NHS and non-NHS countries, depending on national health insurance coverage.

Our results demonstrate that both SPH and FHR health status variables are negatively related to life insurance holdings in the whole sample and in NHS subgroups, indicating that unhealthy households are less likely to hold life insurance. In non-NHS countries, only FHR has negative effects. This implies that households treat national health insurance as a self-insurance mechanism, substituting market insurance for NHS. We also find that older households with higher FHR are more inclined to hold life insurance in the pooled data and non-NHS sample.

There are some interesting findings on the demand for different types of life insurance in the whole sample. The results demonstrate that both SPH and FHR health status indicators have negative impacts on holding term life only and on holding both term life and whole life insurance policies. In contrast, there is no relationship between health status and holding whole life only. It seems that there is no adverse selection problem in the life insurance market, especially in European countries with NHS. Our empirical results may provide policy implications for insurers in European countries in that the marketing strategies for life insurance should consider not only demographic factors, but also household health status and national health insurance coverage.

Author Contributions: Saruultuya Tsendsuren: conduct the analysis and write up the draft; Chu-Shiu Li: initiate the ideas, formulate the problems, do detailed planning, develop the theory and help to write up the draft; Sheng-Chang Peng: assistant to write up the draft, develop the methodology, and give comments to improve the paper from time to time; Wing-Keung Wong: assistant to write up the draft, formulate the problems, and give comments to improve the paper from time to time.

Funding: This research has been supported by Golomt Bank of Mongolia, National Kaohsiung University of Science and Technology, Ming Chuan University, Asia University, China Medical University, Hang Seng Management College, Lingnan University, Research Grants Council (RGC) of Hong Kong (project number 12500915), and Ministry of Science and Technology (MOST) (project number , 104-2410-H-327-001-MY2 and others).

Acknowledgments: The authors thank the Guest Editor, Michael McAleer, Lauren Liu (the Assistant Editor) and two anonymous referees for their valuable comments and suggestions that lead to a significant improvement of an early manuscript. The fourth author would like to thank Robert B. Miller and Howard E. Thompson for their continuous guidance and encouragement.

Conflicts of Interest: The authors declare no conflicts of interest. 


\section{Appendix A}

Table A1. List of variables.

\begin{tabular}{|c|c|c|}
\hline & Variables & Description \\
\hline $\begin{array}{l}\text { Dependent } \\
\text { variables }\end{array}$ & $\begin{array}{l}\text { Life insurance } \\
\text { holding }\end{array}$ & $\begin{array}{l}\text { We consider that an individual has life insurance if that individual positively answered the question, "Do you [or/or/or/or] } \\
\text { [your/your/your/your] [husband/wife/partner/partner] currently own any life insurance policies?" }\end{array}$ \\
\hline \multirow{4}{*}{$\begin{array}{l}\text { Main } \\
\text { independent } \\
\text { variables }\end{array}$} & SPH dummy & $\begin{array}{l}\text { Self-perceived health status, categorical: from } 1 \text { "very good" to } 5 \text { "very bad". The dummy variable measures poor self-perceived } \\
\text { health and takes the value of } 1 \text { whenever average household Perceived Health Status is "fair" (3), "bad" (4), or "very bad" (5), and } \\
\text { takes the value } 0 \text { otherwise. }\end{array}$ \\
\hline & SPH discrete & Self-perceived health status, categorical: from 1 "very good" to 5 "very bad". \\
\hline & $\begin{array}{l}\text { Objective health } \\
\text { status (OHS) }\end{array}$ & $\begin{array}{l}\text { OHS variable is the determinant of current overall health as this variable not only considers the SPH status but also the numbers } \\
\text { of chronic diseases. The higher the score the greater the number and severity of perceived problems. }\end{array}$ \\
\hline & $\begin{array}{l}\text { Future Health Risk } \\
\text { (FHR) }\end{array}$ & $\begin{array}{l}\text { The variable FHR is evaluated by the increasing function of the average number of risky behaviours (smoking, drinking, and a } \\
\text { sedentary lifestyle), the household's Asymptomatic Objective Health Status (measured as the average number of diseases, blood } \\
\text { pressure, blood cholesterol, and osteoporosis), and decreasing function of average household grip strength. The higher the score } \\
\text { the greater the number and severity of perceived problems. We construct this health variable according to the method described } \\
\text { by Atella et al. (2012). }\end{array}$ \\
\hline \multirow{8}{*}{$\begin{array}{l}\text { Demographic } \\
\text { variables }\end{array}$} & Age & $\begin{array}{l}\text { In order to construct age variable, we use respondent's birth year. Age ranges from } 50 \text { to } 90 \text { years, with two subgroups: younger } \\
(50<\text { age }<65) \text { and elderly (aged } \geq 65) \text {. }\end{array}$ \\
\hline & Education & $\begin{array}{l}\text { Education systems in SHARE countries are highly heterogeneous. We follow Atella et al. (2012) to rely on the completed years of } \\
\text { education rather than educational degrees. How many years have you been in full time education (including receiving tuition, } \\
\text { engaging in practical work or supervised study or taking examinations). Possible range is } 0-25 \text { years. High level of education is } \\
\text { defined as the number of completed years of education higher than or equal to } 10 \text { and low level of education is equal to } \\
\text { compulsory full education, which is } 9 \text { years. }\end{array}$ \\
\hline & Marital status & $\begin{array}{l}\text { What is your marital status? 1. Married and living together with spouse, 2. Registered partnership, 3. Married, and living } \\
\text { separated from spouse, } 4 \text {. Never married, } 5 \text {. Divorced, } 6 \text {. Widowed. We define married individuals as those providing one of the } \\
\text { first three answers. }\end{array}$ \\
\hline & With children & How many children do you have that are still alive? Please count all biological, foster, adopted and stepchildren. \\
\hline & Household size & Total number of household members. \\
\hline & $\begin{array}{l}\text { Household income } \\
\text { ('000s euro) }\end{array}$ & $\begin{array}{l}\text { We focus on wave 4, thus Version B (thinc2) is more suitable to our study. Version B is obtained from the one shot question on total } \\
\text { household monthly income. }\end{array}$ \\
\hline & Net wealth & The sum of the financial and real assets of the household (including the value of owned property) net of financial liabilities. \\
\hline & $\begin{array}{l}\text { Pension ('000s } \\
\text { euro) }\end{array}$ & Annual old age \& early retirement pensions (ypen1). \\
\hline
\end{tabular}


Table A1. Cont.

\begin{tabular}{|c|c|c|}
\hline & Variables & Description \\
\hline & $\begin{array}{l}\text { Future retirement } \\
\text { age }\end{array}$ & $\begin{array}{l}\text { The future retirement age for a person who entered the labor force at age 20. Source: OECD.Stat } \\
\text { (https://stats.oecd.org/Index.aspx). }\end{array}$ \\
\hline & $\begin{array}{l}\text { Gross pension } \\
\text { replacement rate }\end{array}$ & $\begin{array}{l}\text { The gross replacement rate is defined as gross pension entitlement divided by gross pre-retirement earnings. Source: OECD.Stat } \\
\text { (https://stats.oecd.org/Index.aspx). }\end{array}$ \\
\hline & $\begin{array}{l}\text { Health spending } \\
\text { from coverage } \\
\text { (billion euro) }\end{array}$ & $\begin{array}{l}\text { The country-level data of health spending from government or compulsory schemes. Source: OECD.Stat } \\
\text { (https://stats.oecd.org/Index.aspx). }\end{array}$ \\
\hline & $\begin{array}{l}\text { Out-of-pocket } \\
\text { health spending } \\
\text { (billion euro) }\end{array}$ & $\begin{array}{l}\text { The country-level data of health spending from voluntary schemes or household out-of-pocket payments. Source: OECD. Stat } \\
\text { (https://stats.oecd.org/Index.aspx). }\end{array}$ \\
\hline & $\begin{array}{l}\text { Prob. of } \\
\text { inheritance }\end{array}$ & $\begin{array}{l}\text { Thinking about the next ten years, what are the chances that you will receive any inheritance, including property and other } \\
\text { valuables ( } 0-100 \text { percent)? }\end{array}$ \\
\hline & $\begin{array}{l}\text { Higher life } \\
\text { expectancy }\end{array}$ & $\begin{array}{l}\text { To define life expectancy, we use the question "What are the chances that you will live to be age } \\
\text { [75/80/85/90/95/100/105/110/120] or more?" Possible choices are between 0-100. High life expectancy defined as higher than } \\
\text { or equal to } 50 \text { percent of the individuals expecting to live at least } 10 \text { years. Less than } 50 \text { percent defines low life expectancy. }\end{array}$ \\
\hline \multirow{2}{*}{$\begin{array}{l}\text { Lifestyle } \\
\text { variables }\end{array}$} & Socially active & $\begin{array}{l}\text { Social participation is defined by the question of "Gone to a sport, social or other kind of club and political or community in the } \\
\text { past twelve months?". We construct this variable by following Christelis et al. (2010), and Atella et al. (2012). }\end{array}$ \\
\hline & $\begin{array}{l}\text { Religious } \\
\text { participation }\end{array}$ & $\begin{array}{l}\text { The general question for religion "Taken part in activities of a religious organization" (church, synagogue, mosque etc.)" following } \\
\text { Christelis et al. (2010), and Atella et al. (2012). }\end{array}$ \\
\hline
\end{tabular}

Table A2. Correlation coefficients of variables.

\begin{tabular}{|c|c|c|c|c|c|c|c|c|c|c|c|c|c|c|c|c|c|c|c|c|c|c|c|c|c|}
\hline & & A & в & c & $\mathrm{D}$ & $\mathrm{E}$ & $\mathrm{F}$ & G & $\mathrm{H}$ & $\mathrm{I}$ & $\mathrm{J}$ & $\mathrm{K}$ & $\mathrm{L}$ & м & $\mathrm{N}$ & $\mathrm{o}$ & $\mathbf{P}$ & $\mathrm{Q}$ & $\mathbf{R}$ & $\mathrm{s}$ & $\mathrm{T}$ & $\mathrm{u}$ & $\mathrm{v}$ & $\mathrm{w}$ & $x$ \\
\hline $\begin{array}{l}\text { Life insurance holdings } \\
\text { OHS }\end{array}$ & ${ }_{\mathrm{B}}^{\mathrm{A}}$ & $\begin{array}{c}1 \\
-0.093^{*} \\
\text {. }\end{array}$ & & & & & & & & & & & & & & & & & & & & & & & \\
\hline SPH dummy & C & $-0.119 *$ & $0.400^{*}$ & & & & & & & & & & & & & & & & & & & & & & \\
\hline$\underset{\text { Age }>65}{\text { FHR }}$ & $\begin{array}{l}\mathrm{D} \\
\mathrm{E}\end{array}$ & $\begin{array}{l}-0.0 .51^{*} \\
-0_{0.24 *^{*}}\end{array}$ & $\begin{array}{l}0.154^{*} \\
0.2226\end{array}$ & $\begin{array}{l}0.153 * \\
0.25 *^{*}\end{array}$ & & & & & & & & & & & & & & & & & & & & & \\
\hline $\begin{array}{l}\text { Age } 263 \text { ducation } \\
\text { Higher eductor }\end{array}$ & $\mathrm{F}$ & 0.105* & $\begin{array}{l}0.226 * \\
-0.128 *\end{array}$ & $\begin{array}{l}0.257 \text { * } \\
-0.110^{*}\end{array}$ & $\begin{array}{l}0.2027 * \\
-0.127 *\end{array}$ & $\begin{array}{l}0.09060^{*} \\
-0.066^{2}\end{array}$ & & & & & & & & & & & & & & & & & & & \\
\hline $\begin{array}{l}\text { Marital status } \\
\text { Srital stus }\end{array}$ & G & $-0.102^{*}$ & $0.099^{*}$ & 0.0795 & $0.094^{*}$ & $0.043^{*}$ & $0.159^{*}$ & $-0.059 *$ & & & & & & & & & & & & & & & & & \\
\hline 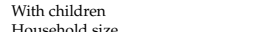 & $\mathrm{H}$ & $0.032 *$ & $\begin{array}{l}-0.000 \\
=0.01 *\end{array}$ & $0.007 *$ & $\begin{array}{l}-0.000 \\
=0.06 *\end{array}$ & -0.000 & $\begin{array}{l}0.006 \\
0.2032 \\
\text {. }\end{array}$ & -0.010 & $-0.380 *$ & 1 & & & & & & & & & & & & & & & \\
\hline $\begin{array}{l}\text { ouusehold size } \\
\text { Household income per capit }\end{array}$ & & $\begin{array}{l}0.0106^{*} \\
0.07\end{array}$ & $\begin{array}{l}-0.0 .011^{*} \\
-0.229\end{array}$ & $\begin{array}{l}-0.0183^{*} \\
-0.104 *\end{array}$ & $\begin{array}{l}-0.0 .460^{*} \\
-0.209^{*}\end{array}$ & $\begin{array}{l}0.002 \\
-0.041 *\end{array}$ & $\begin{array}{l}-0.2933^{*} \\
-0.027\end{array}$ & $\begin{array}{l}0.018 \text { * } \\
0.059\end{array}$ & $\begin{array}{l}-0.063^{*} \\
0.04\end{array}$ & 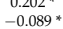 & $-0.297 * * 2>0$ & & & & & & & & & & & & & & \\
\hline $\begin{array}{l}\text { Household income per capitas } \\
\text { Hous }\end{array}$ & $\mathrm{K}$ & $0.096 *$ & $-0.229 *$ & $\begin{array}{l}-0.104 * \\
-0.104\end{array}$ & $-0.209 *$ & $-0.041 *$ & 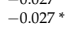 & $0.059 *$ & $0.063^{*}$ & $-0.089 *$ & $-0.299 *$ * $>0$ & $1.000 *$ & & & & & & & & & & & & & \\
\hline $\begin{array}{l}\text { Net wealth per capita } \\
\text { Nalth }\end{array}$ & $\mathrm{L}$ & $0.129 *$ & $-0.200 *$ & $-0.120 * *$ & $-0.183 * *$ & $-0.081 *$ & -0.010 & $0.123 *$ & $-0.123 *$ & -0.000 & 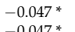 & $0.193^{*}$ & $0.193 *$ & & & & & & & & & & & & \\
\hline $\begin{array}{l}\text { Net tealth per capita squared } \\
\text { Pension }\end{array}$ & & $\begin{array}{l}0.1299^{*} \\
-0.170^{*}\end{array}$ & $\begin{array}{l}-0.200 * \\
0.097 *\end{array}$ & - $\begin{array}{c}-0.120 * \\
0.140^{*}\end{array}$ & 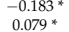 & - $\begin{array}{c}-0.021^{*} \\
0.02 *^{2}\end{array}$ & ${ }^{-0.0010} 0^{0}$ & $\begin{array}{l}0.123 * \\
-0.075 *\end{array}$ & $\begin{array}{l}-0.123^{*} \\
0.056 *\end{array}$ & $\begin{array}{c}-0.000 \\
0.009\end{array}$ & $\begin{array}{l}-0.0475^{*} \\
-0.21\end{array}$ & $\begin{array}{l}0.193 * \\
0.014^{*}\end{array}$ & $\begin{array}{l}0.1934^{*} \\
0.014 * x \\
\end{array}$ & 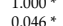 & & & & & & & & & & & \\
\hline Probability of receiving inheritan & 0 & $0.148^{*}$ & -0.190* & 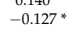 & $\begin{array}{l}0.0167 * \\
-0.76\end{array}$ & $\begin{array}{l}0.026 * \\
-0.054 *\end{array}$ & $-0.289 *$ & $0.124^{*}$ & $-0.085 *$ & -0.010 & $0.090^{*}$ & $0.1177^{*}$ & $0.117^{*}+40$ & $0.113^{*}$ & $0.113^{*}$ & $-0.210^{*}$ & & & & & & & & & \\
\hline Health spending from coverage & & $0.032 *$ & $-0.157 *$ & $-0.081 *$ & $-0.175 *$ & $0.017 *$ & $0.022^{*}$ & $-0.110^{*}$ & $-0.063^{*}$ & $-0.027 * *$ & $0.024^{*}$ & $0.241^{*}$ & $0.241 *$ & 0.05 & $0.093^{*} *$ & -0.000 & $0.100^{*}$ & & & & & & & & \\
\hline $\begin{array}{l}\text { Out-of-pockethealth spending } \\
\text { Hicher life expectancy }\end{array}$ & ${ }_{\mathrm{C}}^{\mathrm{R}}$ & $0.024 *$ & -0.151 * & $\begin{array}{l}-0.079 * \\
-0.26 *\end{array}$ & $-0.170^{*} *$ & $\begin{array}{l}0.017 * \\
-0.010\end{array}$ & 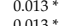 & $-0.147 * *$ & 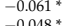 & $-0.036^{*}$ & 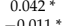 & 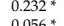 & 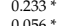 & 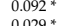 & 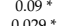 & $-0.0100^{*}$ & 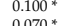 & & & & & & & & \\
\hline 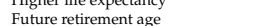 & & $\begin{array}{l}-0.048^{*} \\
-0.028^{*}\end{array}$ & $\begin{array}{l}-0.105 * \\
-0.109 *\end{array}$ & $\begin{array}{l}-0.0261^{*} \\
-{ }_{-0.040}\end{array}$ & $\begin{array}{l}-0.0 .045^{*} \\
-{ }_{-0.075}\end{array}$ & $\begin{array}{l}-0.0170 \\
0.017 *\end{array}$ & $\begin{array}{l}0.0109 \\
0.009\end{array}$ & 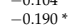 & 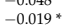 & 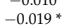 & 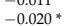 & 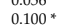 & 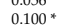 & 0.034* & 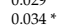 & $\begin{array}{l}2 \\
-0.030 *\end{array}$ & $0.000 *$ & $0.0338^{*}$ & 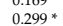 & $0746 *$ & & & & & \\
\hline Gross pension replacen & $\mathrm{u}$ & $0.104 * * 2,4$ & $-0.286 *$ & $-0.211^{*} *$ & $-0.258^{*}$ & $-0.078^{*}+2$ & $-0.231 *$ & $0.066 *$ & $-0.097 *$ & 0.010 & $0.063^{*}$ & $0.110^{*}$ & $0.110^{*}$ & $0.120^{*}$ & $0.120^{*}+20$ & $-0.10^{*}$ & $0.151 * * 20$ & & & & & & & & \\
\hline & & $0.109 * *$ & $-0.238^{*} *$ & $-0.114^{*}$ & $-0.204^{*} * x<1$ & $-0.065^{*}$ & $-0.0880^{*}$ & $0.129^{* *}$ & $-0.0644^{*}$ & 0.02 & -0.0000 & $0.146^{*}$ & 0.146" & 0.1 & $0.150^{*} *$ & -0.0100 & $0.130^{*}$ & $0.0599^{*}$ & & 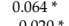 & & ${ }^{28 *} *$ & & & \\
\hline $\begin{array}{l}\text { Non-NHS } \\
\text { Norigl }\end{array}$ & $\begin{array}{l}n \\
x\end{array}$ & & $\begin{array}{l}-0.249 * \\
-0.019\end{array}$ & $\begin{array}{l}0.116 * \\
-0.000\end{array}$ & & & $0.013^{*}$ & & & & & $\begin{array}{l}-0.340 \\
0.34 * \\
4\end{array}$ & $\begin{array}{l}-0.347 \\
0.34\end{array}$ & & & $\begin{array}{l}0.030 * \\
-0.020\end{array}$ & $0.162^{*}$ & 0 & $\begin{array}{l}0.742^{*} \\
0.74\end{array}$ & 0 & $0.528^{*}$ & . & . & 0.020 * & \\
\hline
\end{tabular}

Note: * is significance level at 0.05 . Some of the control variables are highly correlated. For example, the correlation coefficient between age and SPH good is 0.23 . This is likely to cause multi-collinearity problem during multivariate regression analyses. However, we checked the variance inflation factors (VIF). There are no VIF values greater than 5 , indicating no multi-collinearity among the variables. 
Table A3. Probit regression of purchasing life insurance by whole sample, Age 50+

\begin{tabular}{|c|c|c|c|c|c|c|}
\hline \multirow{2}{*}{ Dep. var.: Binary for Holding Life Insurance } & \multicolumn{6}{|c|}{ The Whole Sample $(\mathrm{N}=34,341)$} \\
\hline & Model 1 & Model 2 & Model 3 & Model 4 & Model 5 & Model 6 \\
\hline FHR & & & $\begin{array}{c}-0.0136^{* * *} \\
(0.004)\end{array}$ & & & $\begin{array}{c}-0.0144^{* * *} \\
(0.006)\end{array}$ \\
\hline \multicolumn{7}{|l|}{ Demographic variables } \\
\hline Higher education & $\begin{array}{c}0.0220^{* * *} \\
(0.005)\end{array}$ & $\begin{array}{c}0.0232^{* * *} \\
(0.005)\end{array}$ & $\begin{array}{c}0.0232^{* * *} \\
(0.005)\end{array}$ & $\begin{array}{c}0.0193^{* * *} \\
(0.005)\end{array}$ & $\begin{array}{c}0.0204^{* * *} \\
(0.005)\end{array}$ & $\begin{array}{c}0.0204^{* * *} \\
(0.005)\end{array}$ \\
\hline \multicolumn{7}{|l|}{ Marital status (ref: Never married) } \\
\hline Married & $\begin{array}{c}0.0565^{* * *} \\
(0.009)\end{array}$ & $\begin{array}{c}0.0570^{* * *} \\
(0.009)\end{array}$ & $\begin{array}{c}0.0571^{* * *} \\
(0.009)\end{array}$ & $\begin{array}{c}0.0563^{* * *} \\
(0.009)\end{array}$ & $\begin{array}{c}0.0568^{* * *} \\
(0.009)\end{array}$ & $\begin{array}{c}0.0568^{* * *} \\
(0.009)\end{array}$ \\
\hline Divorced & $\begin{array}{c}0.014 \\
(0.010)\end{array}$ & $\begin{array}{l}0.0142 \\
(0.010)\end{array}$ & $\begin{array}{l}0.0143 \\
(0.010)\end{array}$ & $\begin{array}{c}0.013 \\
(0.010)\end{array}$ & $\begin{array}{l}0.0133 \\
(0.010)\end{array}$ & $\begin{array}{l}0.0133 \\
(0.010)\end{array}$ \\
\hline Household income per capita & $\begin{array}{c}0.0226^{* * *} \\
(0.003)\end{array}$ & $\begin{array}{c}0.0236^{* * * *} \\
(0.003)\end{array}$ & $\begin{array}{c}0.0235^{* * * *} \\
(0.003)\end{array}$ & $\begin{array}{c}0.0232 * * * \\
(0.003)\end{array}$ & $\begin{array}{c}0.0242^{* * * *} \\
(0.003)\end{array}$ & $\begin{array}{c}0.0242^{* * *} \\
(0.003)\end{array}$ \\
\hline Household income per capita squared & $\begin{array}{c}0.000 \\
(0.000)\end{array}$ & $\begin{array}{c}0.000 \\
(0.000)\end{array}$ & $\begin{array}{c}0.000 \\
(0.000)\end{array}$ & $\begin{array}{c}0.000 \\
(0.000)\end{array}$ & $\begin{array}{c}0.000 \\
(0.000)\end{array}$ & $\begin{array}{c}0.000 \\
(0.000)\end{array}$ \\
\hline Net wealth per capita & $\begin{array}{c}0.0149 * * * \\
(0.001)\end{array}$ & $\begin{array}{c}0.0152 * * * \\
(0.001)\end{array}$ & $\begin{array}{c}0.0151 * * * \\
(0.001)\end{array}$ & $\begin{array}{c}0.0152 * * * \\
(0.001)\end{array}$ & $\begin{array}{c}0.0154^{* * *} \\
(0.001)\end{array}$ & $\begin{array}{c}0.0154^{* * *} \\
(0.001)\end{array}$ \\
\hline Net wealth per capita squared & $\begin{array}{c}0.000 \\
(0.000)\end{array}$ & $\begin{array}{c}0.000 \\
(0.000)\end{array}$ & $\begin{array}{c}0.000 \\
(0.000)\end{array}$ & $\begin{array}{c}0.000 \\
(0.000)\end{array}$ & $\begin{array}{c}0.000 \\
(0.000)\end{array}$ & $\begin{array}{c}0.000 \\
(0.000)\end{array}$ \\
\hline Prob. of receiving inheritance & $\begin{array}{c}0.000633^{* * *} \\
(0.000)\end{array}$ & $\begin{array}{c}0.000646^{\text {*** }} \\
(0.000)\end{array}$ & $\begin{array}{c}0.000644^{* * *} \\
(0.000)\end{array}$ & $\begin{array}{c}0.000651^{* * *} \\
(0.000)\end{array}$ & $\begin{array}{c}0.000665^{* * *} \\
(0.000)\end{array}$ & $\begin{array}{c}0.000662^{* * * *} \\
(0.000)\end{array}$ \\
\hline Pension & $\begin{array}{c}-0.00419 * * * \\
(0.001)\end{array}$ & $\begin{array}{c}-0.00412 * * * \\
(0.001)\end{array}$ & $\begin{array}{c}-0.00419 * * * \\
(0.001)\end{array}$ & $\begin{array}{c}-0.00442 * * * \\
(0.001)\end{array}$ & $\begin{array}{c}-0.00438^{* * *} \\
(0.001)\end{array}$ & $\begin{array}{c}-0.00440 \text { *** } \\
(0.001)\end{array}$ \\
\hline
\end{tabular}


Table A3. Cont.



Note: This table reports mean marginal effects evaluated at each observation. Monetary amounts are PPP-adjusted and in thousand Euros. The dummy SPH variable refers to SPH $=1$ if poor health (indicating level 3, 4, or 5) and SPH $=0$ if good health (indicating level 1 for very good, 2 for good). OHS variable is the determinant of current overall health as this variable not only considers the SPH status but also the numbers of chronic diseases. FHR evaluates the increasing function of the average number of risky behaviors (smoking, drinking, and a sedentary lifestyle), the household's Asymptomatic Objective Health Status (measured as the average number of diseases, blood pressure, blood cholesterol, and osteoporosis), and decreasing function of average household grip strength. Standard errors in parentheses, ${ }^{* * *} p<0.01,{ }^{* *} p<0.05,{ }^{*} p<0.1$. Source: the SHARE data and OECD.Stat (https://stats.oecd.org/Index.aspx). 
Table A4. Probit regression of purchasing life insurance by different NHS, Age 50+.

\begin{tabular}{|c|c|c|c|c|c|c|}
\hline \multirow{2}{*}{ Dep. var.: Life Insurance Holding } & \multicolumn{3}{|c|}{ Non-NHS $(\mathrm{N}=14,958)$} & \multicolumn{3}{|c|}{ NHS $(\mathrm{N}=19,383)$} \\
\hline & Model 1 & Model 2 & Model 3 & Model 4 & Model 5 & Model 6 \\
\hline SPH dummy & $\begin{array}{c}-0.00278 \\
(0.008)\end{array}$ & & & $\begin{array}{c}-0.0295^{* * *} \\
(0.006)\end{array}$ & & \\
\hline OHS & & $\begin{array}{l}0.0245 \\
(0.029) \\
\end{array}$ & & & $\begin{array}{c}-0.0521 \text { *** } \\
(0.020)\end{array}$ & \\
\hline FHR & & & $\begin{array}{c}-0.0160 \text { *** } \\
(0.005)\end{array}$ & & & $\begin{array}{c}-0.0117^{* *} \\
(0.005)\end{array}$ \\
\hline \multicolumn{7}{|l|}{ Demographic variables } \\
\hline Age $\geq 65$ & $\begin{array}{c}-0.153 * * * \\
(0.011)\end{array}$ & $\begin{array}{c}-0.154^{* * *} \\
(0.011)\end{array}$ & $\begin{array}{c}-0.151^{* * *} \\
(0.011)\end{array}$ & $\begin{array}{c}-0.0923 * * * \\
(0.008)\end{array}$ & $\begin{array}{c}-0.0938 \text { *** } \\
(0.008)\end{array}$ & $\begin{array}{c}-0.0956^{* * *} \\
(0.008)\end{array}$ \\
\hline Higher education & $\begin{array}{c}0.0128^{*} \\
(0.007)\end{array}$ & $\begin{array}{c}0.0134^{*} \\
(0.007)\end{array}$ & $\begin{array}{l}0.0124 * \\
(0.007)\end{array}$ & $\begin{array}{c}0.0242^{* * *} \\
(0.006)\end{array}$ & $\begin{array}{c}0.0264^{* * *} \\
(0.006)\end{array}$ & $\begin{array}{c}0.0271^{* * *} \\
(0.006)\end{array}$ \\
\hline \multicolumn{7}{|l|}{ Marital status (ref: Never married) } \\
\hline Married & $\begin{array}{c}0.0531 * * * \\
(0.014)\end{array}$ & $\begin{array}{c}0.0532 * * * \\
(0.014)\end{array}$ & $\begin{array}{c}0.0532 * * * \\
(0.014)\end{array}$ & $\begin{array}{c}0.0527^{* * *} \\
(0.012)\end{array}$ & $\begin{array}{c}0.0536^{* * *} \\
(0.012)\end{array}$ & $\begin{array}{c}0.0536^{* * *} \\
(0.012)\end{array}$ \\
\hline Divorced & $\begin{array}{l}0.0209 \\
(0.016)\end{array}$ & $\begin{array}{l}0.0207 \\
(0.016)\end{array}$ & $\begin{array}{l}0.0213 \\
(0.016) \\
\end{array}$ & $\begin{array}{c}-0.00188 \\
(0.014)\end{array}$ & $\begin{array}{c}-0.00138 \\
(0.014)\end{array}$ & $\begin{array}{c}-0.00175 \\
(0.014)\end{array}$ \\
\hline Widowed & $\begin{array}{c}-0.00816 \\
(0.016)\end{array}$ & $\begin{array}{c}-0.00869 \\
(0.016)\end{array}$ & $\begin{array}{c}-0.00726 \\
(0.016)\end{array}$ & $\begin{array}{l}-0.015 \\
(0.013)\end{array}$ & $\begin{array}{c}-0.0146 \\
(0.013) \\
\end{array}$ & $\begin{array}{c}-0.0152 \\
(0.013) \\
\end{array}$ \\
\hline With children & $\begin{array}{c}0.0300^{* * *} \\
(0.011)\end{array}$ & $\begin{array}{c}0.0302^{* * *} \\
(0.011)\end{array}$ & $\begin{array}{c}0.0298^{* * *} \\
(0.011)\end{array}$ & $\begin{array}{c}0.0302^{* * *} \\
(0.011)\end{array}$ & $\begin{array}{c}0.0307^{* * *} \\
(0.011)\end{array}$ & $\begin{array}{c}0.0308^{* * *} \\
(0.011)\end{array}$ \\
\hline Household income per capita & $\begin{array}{c}0.0174 * * * \\
(0.004)\end{array}$ & $\begin{array}{c}0.0176^{* * *} \\
(0.004)\end{array}$ & $\begin{array}{c}0.0174^{* * *} \\
(0.004)\end{array}$ & $\begin{array}{c}0.0291 * * * \\
(0.003)\end{array}$ & $\begin{array}{c}0.0299 * * * \\
(0.003)\end{array}$ & $\begin{array}{c}0.0299 * * * \\
(0.003)\end{array}$ \\
\hline Household income per capita squared & $\begin{array}{c}0.000 \\
(0.000)\end{array}$ & $\begin{array}{c}0.000 \\
(0.000)\end{array}$ & $\begin{array}{c}0.000 \\
(0.000)\end{array}$ & $\begin{array}{c}0.000 \\
(0.000)\end{array}$ & $\begin{array}{c}0.000 \\
(0.000)\end{array}$ & $\begin{array}{c}0.000 \\
(0.000)\end{array}$ \\
\hline Net wealth per capita & $\begin{array}{c}0.0186^{* * *} \\
(0.001)\end{array}$ & $\begin{array}{c}0.0187^{* * *} \\
(0.001)\end{array}$ & $\begin{array}{c}0.0184^{* * *} \\
(0.001)\end{array}$ & $\begin{array}{c}0.0162^{* * *} \\
(0.001)\end{array}$ & $\begin{array}{c}0.0165^{* * *} \\
(0.001)\end{array}$ & $\begin{array}{c}0.0166^{* * *} \\
(0.001)\end{array}$ \\
\hline Net wealth per capita squared & $\begin{array}{c}0.000 \\
(0.000)\end{array}$ & $\begin{array}{c}0.000 \\
(0.000)\end{array}$ & $\begin{array}{c}0.000 \\
(0.000)\end{array}$ & $\begin{array}{c}0.000 \\
(0.000)\end{array}$ & $\begin{array}{c}0.000 \\
(0.000)\end{array}$ & $\begin{array}{c}0.000 \\
(0.000)\end{array}$ \\
\hline Prob. of receiving inheritance & $\begin{array}{c}0.00054^{* * * *} \\
(0.000)\end{array}$ & $\begin{array}{c}0.00054^{* * *} \\
(0.000)\end{array}$ & $\begin{array}{c}0.00054^{* * *} \\
(0.000)\end{array}$ & $\begin{array}{c}0.000896^{* * *} \\
(0.000)\end{array}$ & $\begin{array}{c}0.00092 * * * \\
(0.000)\end{array}$ & $\begin{array}{c}0.00092^{* * *} \\
(0.000)\end{array}$ \\
\hline Pension & $\begin{array}{c}-0.0054^{* * *} \\
(0.001)\end{array}$ & $\begin{array}{c}-0.0054^{* * *} \\
(0.001)\end{array}$ & $\begin{array}{c}-0.0054^{* * *} \\
(0.001)\end{array}$ & $\begin{array}{c}-0.00455^{* * *} \\
(0.001)\end{array}$ & $\begin{array}{c}-0.0044^{* * *} \\
(0.001)\end{array}$ & $\begin{array}{c}-0.00446^{* * *} \\
(0.001)\end{array}$ \\
\hline Future retirement age & $\begin{array}{c}-0.0200 * * * \\
(0.003)\end{array}$ & $\begin{array}{c}-0.0199 * * * \\
(0.003)\end{array}$ & $\begin{array}{c}-0.0204^{* * *} \\
(0.003)\end{array}$ & $\begin{array}{c}0.00499 * * * \\
(0.002)\end{array}$ & $\begin{array}{c}0.00474^{* *} \\
(0.002)\end{array}$ & $\begin{array}{c}0.00452^{* *} \\
(0.002)\end{array}$ \\
\hline Gross pension replacement rate & $\begin{array}{c}0.00140 * * * \\
(0.000)\end{array}$ & $\begin{array}{c}0.00141^{* * *} \\
(0.000)\end{array}$ & $\begin{array}{c}0.00142 * * * \\
(0.000)\end{array}$ & $\begin{array}{c}-0.00501 * * * \\
(0.000)\end{array}$ & $\begin{array}{c}-0.00494 * * * \\
(0.000)\end{array}$ & $\begin{array}{c}-0.00492 * * * \\
(0.000)\end{array}$ \\
\hline
\end{tabular}


Table A4. Cont.

\begin{tabular}{|c|c|c|c|c|c|c|}
\hline \multirow{2}{*}{ Dep. var.: Life Insurance Holding } & \multicolumn{3}{|c|}{ Non-NHS $(\mathrm{N}=14,958)$} & \multicolumn{3}{|c|}{ NHS $(\mathrm{N}=19,383)$} \\
\hline & Model 1 & Model 2 & Model 3 & Model 4 & Model 5 & Model 6 \\
\hline Health spending from coverage & $\begin{array}{c}0.116 * * * \\
(0.014)\end{array}$ & $\begin{array}{c}0.115 * * * \\
(0.014)\end{array}$ & $\begin{array}{c}0.117 * * * \\
(0.013)\end{array}$ & $\begin{array}{c}0.007 \\
(0.011)\end{array}$ & $\begin{array}{c}0.012 \\
(0.011)\end{array}$ & $\begin{array}{l}0.0139 \\
(0.011)\end{array}$ \\
\hline Out-of-pocket health spending & $\begin{array}{c}-0.154^{* * *} \\
(0.015)\end{array}$ & $\begin{array}{c}-0.153^{* * * *} \\
(0.015)\end{array}$ & $\begin{array}{c}-0.155^{* * *} \\
(0.015)\end{array}$ & $\begin{array}{l}0.0151 \\
(0.011)\end{array}$ & $\begin{array}{l}0.0112 \\
(0.011)\end{array}$ & $\begin{array}{c}0.00968 \\
(0.011)\end{array}$ \\
\hline Higher Life expectancy & $\begin{array}{c}0.0447^{* * *} \\
(0.009)\end{array}$ & $\begin{array}{c}0.0463 * * * \\
(0.008)\end{array}$ & $\begin{array}{c}0.0440^{* * * *} \\
(0.008)\end{array}$ & $\begin{array}{c}0.0356^{* * *} \\
(0.006)\end{array}$ & $\begin{array}{c}0.0384^{* * *} \\
(0.006)\end{array}$ & $\begin{array}{c}0.0400^{* * * *} \\
(0.006)\end{array}$ \\
\hline Social activity & $\begin{array}{c}0.0273^{* * *} \\
(0.007)\end{array}$ & $\begin{array}{c}0.0279 * * * \\
(0.007)\end{array}$ & $\begin{array}{c}0.0268^{* * *} \\
(0.007)\end{array}$ & $\begin{array}{c}0.0647^{* * *} \\
(0.007)\end{array}$ & $\begin{array}{c}0.0680^{* * *} \\
(0.007)\end{array}$ & $\begin{array}{c}0.0683^{* * * *} \\
(0.007)\end{array}$ \\
\hline Religious participation & $\begin{array}{c}-0.0155 \\
(0.009)\end{array}$ & $\begin{array}{c}-0.0154 \\
(0.009)\end{array}$ & $\begin{array}{c}-0.0154 \\
(0.009)\end{array}$ & $\begin{array}{c}0.0328^{* * *} \\
(0.008)\end{array}$ & $\begin{array}{c}0.0340^{* * *} \\
(0.008)\end{array}$ & $\begin{array}{c}0.0336^{* * *} \\
(0.008)\end{array}$ \\
\hline Pseudo $R^{2}$ & 0.093 & 0.093 & 0.093 & 0.123 & 0.123 & 0.123 \\
\hline Log likelihood & -7516.404 & -7516.1 & 7511.61 & -8135.99 & -8145.81 & -8146.52 \\
\hline
\end{tabular}

Note: Mean marginal effects evaluated at each observation. Monetary amounts are PPP-adjusted and in thousand Euros. The dummy SPH variable refers to SPH $=1$ if poor health (indicating level 3,4 , or 5 ) and SPH $=0$ if good health (indicating level 1 for very good, 2 for good). OHS variable is the determinant of current overall health as this variable not only considers the SPH status but also the numbers of chronic diseases. FHR evaluates the increasing function of the average number of risky behaviors (smoking, drinking, and a sedentary lifestyle), the household's Asymptomatic Objective Health Status (measured as the average number of diseases, blood pressure, blood cholesterol, and osteoporosis), and decreasing function of average household grip strength. Standard errors in parentheses, ${ }^{* * *} p<0.01,{ }^{* *} p<0.05,{ }^{*} p<0.1$ Source: the SHARE data and OECD.Stat (https://stats.oecd.org/Index.aspx). 
Table A5. Interaction terms with three health status indicators and higher education, whole sample, NHS countries, and Non-NHS countries, Age 50+.

\begin{tabular}{|c|c|c|c|c|c|c|c|c|c|}
\hline Dep. var.: Life Insurance Holding & \multicolumn{3}{|c|}{ The Whole Sample $(\mathrm{N}=34,341)$} & \multicolumn{3}{|c|}{ Non-NHS $(\mathrm{N}=14,958)$} & \multicolumn{3}{|c|}{ NHS $(N=19,383)$} \\
\hline SPH dummy & $\begin{array}{c}-0.0158^{* *} \\
(0.007)\end{array}$ & & & $\begin{array}{c}0.00203 \\
(0.012)\end{array}$ & & & $\begin{array}{c}-0.0235^{* *} \\
(0.009)\end{array}$ & & \\
\hline OHS & & $\begin{array}{l}-0.0103 \\
(0.024)\end{array}$ & & & $\begin{array}{l}0.0377 \\
(0.040)\end{array}$ & & & $\begin{array}{c}-0.0281 \\
(0.028)\end{array}$ & \\
\hline FHR & & & $\begin{array}{c}-0.0109 \text { ** } \\
(0.005)\end{array}$ & & & $\begin{array}{c}-0.0142 * \\
(0.008)\end{array}$ & & & $\begin{array}{c}-0.00833 \\
(0.008)\end{array}$ \\
\hline \multicolumn{10}{|l|}{ Demographic variables } \\
\hline Age $\geq 65$ & $\begin{array}{c}-0.128^{* * * *} \\
(0.007)\end{array}$ & $\begin{array}{c}-0.129^{* * * *} \\
(0.007)\end{array}$ & $\begin{array}{c}-0.129 * * * \\
(0.007)\end{array}$ & $\begin{array}{c}-0.153 * * * * \\
(0.011)\end{array}$ & $\begin{array}{c}-0.154^{* * * *} \\
(0.011)\end{array}$ & $\begin{array}{c}-0.151^{* * *} \\
(0.011)\end{array}$ & $\begin{array}{l}-0.0924 * * * \\
(0.008)\end{array}$ & $\begin{array}{c}-0.0937 * * * \\
(0.008)\end{array}$ & $\begin{array}{c}-0.0957 * * * \\
(0.008)\end{array}$ \\
\hline Higher education & $\begin{array}{c}0.0257^{* * *} \\
(0.006)\end{array}$ & $\begin{array}{c}0.0265^{* * *} \\
(0.005)\end{array}$ & $\begin{array}{c}0.0246^{* * *} \\
(0.005)\end{array}$ & $\begin{array}{l}0.0152 * \\
(0.009)\end{array}$ & $\begin{array}{l}0.0154^{*} \\
(0.009)\end{array}$ & $\begin{array}{l}0.0134^{*} \\
(0.008)\end{array}$ & $\begin{array}{c}0.0284^{* * *} \\
(0.008)\end{array}$ & $\begin{array}{c}0.0309 * * * \\
(0.007)\end{array}$ & $\begin{array}{c}0.0287^{* * *} \\
(0.007)\end{array}$ \\
\hline SPH dummy $\times$ Higher education & $\begin{array}{c}-0.0101 \\
(0.009)\end{array}$ & & & $\begin{array}{c}-0.00832 \\
(0.015)\end{array}$ & & & $\begin{array}{c}-0.00926 \\
(0.011)\end{array}$ & & \\
\hline OHS $\times$ Higher education & & $\begin{array}{l}-0.0358 \\
(0.032)\end{array}$ & & & $\begin{array}{l}-0.0253 \\
(0.055)\end{array}$ & & & $\begin{array}{l}-0.0448 \\
(0.038)\end{array}$ & \\
\hline FHR $\times$ Higher education & & & $\begin{array}{c}-0.00505 \\
(0.007)\end{array}$ & & & $\begin{array}{c}-0.00339 \\
(0.010)\end{array}$ & & & $\begin{array}{c}-0.00591 \\
(0.010)\end{array}$ \\
\hline Other controls & \multicolumn{9}{|c|}{$\begin{array}{l}\text { Marital status, with child, Household income per capita, Household income per capita squared, Net wealth per capita, Net wealth per } \\
\text { capita squared, Probability of receiving inheritance, Pension, Future retirement age, Gross pension replacement rate, Health spending from } \\
\text { coverage, Out-of-pocket health spending, Higher life expectancy, Social activity, Religious participation, and Country dummy }\end{array}$} \\
\hline Pseudo $\mathrm{R}^{2}$ & 0.101 & 0.101 & 0.101 & 0.101 & 0.093 & 0.093 & 0.123 & 0.123 & 0.123 \\
\hline Log likelihood & $-15,864.79$ & $-15,874.13$ & $-15,868.79$ & -7516.2 & -7515.99 & -7511.56 & -8135.65 & -8145.12 & -8146.35 \\
\hline
\end{tabular}

Note: Means of marginal effects evaluated at each observation. Monetary amounts are PPP-adjusted and in thousand Euros. The dummy SPH variable refers to SPH $=1$ if poor health (indicating level 3,4 , or 5 ) and SPH $=0$ if good health (indicating level 1 for very good, 2 good). OHS variable is the determinant of current overall health as this variable not only considers the SPH status but also the numbers of chronic diseases. FHR evaluates the increasing function of the average number of risky behaviors (smoking, drinking, and a sedentary lifestyle), the household's Asymptomatic Objective Health Status (measured as the average number of diseases, blood pressure, blood cholesterol, and osteoporosis), and decreasing function of average household grip strength. Standard errors in parentheses, ${ }^{* * *} p<0.01,{ }^{* *} p<0.05,{ }^{*} p<0.1$. Source: the SHARE data and OECD.Stat (https:/ / stats.oecd.org/Index.aspx). 
Table A6. Interaction terms with three health status indicators and Age $\geq 65$, whole sample, NHS countries, and Non-NHS countries, Age 50+.

\begin{tabular}{|c|c|c|c|c|c|c|c|c|c|}
\hline Dep. var.: Life Insurance Holding & \multicolumn{3}{|c|}{ The Whole Sample $(\mathrm{N}=34,341)$} & \multicolumn{3}{|c|}{ Non-NHS $(\mathrm{N}=14,958)$} & \multicolumn{3}{|c|}{ NHS $(\mathrm{N}=19,383)$} \\
\hline SPH dummy & $\begin{array}{c}-0.0223 * * * \\
(0.007)\end{array}$ & & & $\begin{array}{c}-0.0121 \\
(0.012)\end{array}$ & & & $\begin{array}{c}-0.0192 * * \\
(0.008)\end{array}$ & & \\
\hline OHS & & $\begin{array}{c}-0.0233 \\
(0.030)\end{array}$ & & & $\begin{array}{l}-0.00657 \\
(0.053)\end{array}$ & & & $\begin{array}{c}-0.0181 \\
(0.035)\end{array}$ & \\
\hline FHR & & & $\begin{array}{c}-0.0258 * * * \\
(0.007)\end{array}$ & & & $\begin{array}{l}-0.0371 * * * \\
(0.010)\end{array}$ & & & $\begin{array}{c}-0.0137 \\
(0.009)\end{array}$ \\
\hline \multicolumn{10}{|l|}{ Demographic variables } \\
\hline Age $\geq 65$ & $\begin{array}{c}-0.128^{* * *} \\
(0.007)\end{array}$ & $\begin{array}{c}-0.128^{* * *} \\
(0.007)\end{array}$ & $\begin{array}{c}-0.134^{* * *} \\
(0.007)\end{array}$ & $\begin{array}{c}-0.157^{* * *} \\
(0.012)\end{array}$ & $\begin{array}{c}-0.157^{* * *} \\
(0.012)\end{array}$ & $\begin{array}{c}-0.161^{* * *} \\
(0.011)\end{array}$ & $\begin{array}{c}-0.0838^{* * *} \\
(0.009)\end{array}$ & $\begin{array}{c}-0.0891^{* * *} \\
(0.009)\end{array}$ & $\begin{array}{l}-0.0964^{* * * *} \\
(0.009)\end{array}$ \\
\hline Higher education & $\begin{array}{c}0.0220^{* * *} \\
(0.005)\end{array}$ & $\begin{array}{c}0.0232^{* * *} \\
(0.005)\end{array}$ & $\begin{array}{c}0.0232 * * * \\
(0.005)\end{array}$ & $\begin{array}{l}0.0131^{*} \\
(0.007)\end{array}$ & $\begin{array}{l}0.0133^{*} \\
(0.007)\end{array}$ & $\begin{array}{l}0.0124^{*} \\
(0.007)\end{array}$ & $\begin{array}{c}0.0240^{* * *} \\
(0.006)\end{array}$ & $\begin{array}{c}0.0264^{* * *} \\
(0.006)\end{array}$ & $\begin{array}{c}0.0271^{* * *} \\
(0.006)\end{array}$ \\
\hline SPH poor $\times$ Age $\geq 65$ & $\begin{array}{c}0.000605 \\
(0.009) \\
\end{array}$ & & & $\begin{array}{c}0.016 \\
(0.015)\end{array}$ & & & $\begin{array}{c}-0.0187 * \\
(0.011)\end{array}$ & & \\
\hline OHS $\times$ Age $\geq 65$ & & $\begin{array}{c}-0.00845 \\
(0.035)\end{array}$ & & & $\begin{array}{l}0.0435 \\
(0.062)\end{array}$ & & & $\begin{array}{c}-0.0498 \\
(0.042)\end{array}$ & \\
\hline FHR $\times$ Age $\geq 65$ & & & $\begin{array}{c}0.0177^{* *} \\
(0.008)\end{array}$ & & & $\begin{array}{c}0.0312 * * * \\
(0.011)\end{array}$ & & & $\begin{array}{l}0.0028 \\
(0.011)\end{array}$ \\
\hline Other controls & $\begin{array}{l}\text { Marital statu } \\
\text { capita square } \\
\text { coverage, Ou }\end{array}$ & $\begin{array}{l}\text { with child, H } \\
\text { Probability o } \\
\text { of-pocket hea }\end{array}$ & $\begin{array}{l}\text { sehold incom } \\
\text { eceiving inher } \\
\text { spending, Hi }\end{array}$ & $\begin{array}{l}\text { er capita, } \mathrm{H} \\
\text { ance, Pension } \\
\text { ter life expec }\end{array}$ & $\begin{array}{l}\text { ehold incom } \\
\text { dture retirem } \\
\text { cy, Social act }\end{array}$ & $\begin{array}{l}\text { er capita squ } \\
\text { tage, Gross } \\
\text { ty, Religious }\end{array}$ & $\begin{array}{l}\text { ed, Net wealth } \\
\text { sion replacem } \\
\text { rticipation, an }\end{array}$ & $\begin{array}{l}\text { er capita, Net } \\
\text { th rate Health } \\
\text { Country dum }\end{array}$ & $\begin{array}{l}\text { vealth per } \\
\text { pending from } \\
\text { hy }\end{array}$ \\
\hline Pseudo $\mathrm{R}^{2}$ & 0.101 & 0.101 & 0.101 & 0.093 & 0.093 & 0.093 & 0.123 & 0.123 & 0.123 \\
\hline Log likelihood & $-15,865.4$ & $-15,874.73$ & $-15,866.48$ & -7515.85 & -7515.85 & -7507.71 & -8134.48 & -8145.09 & -8146.49 \\
\hline
\end{tabular}

Note: Means of marginal effects evaluated at each observation. Monetary amounts are PPP-adjusted and in thousand Euros. The dummy SPH variable refers to SPH $=1$ if poor health (indicating level 3,4 , or 5) and SPH $=0$ if good health (indicating level 1 for very good, 2 good). OHS variable is the determinant of current overall health as this variable not only considers the SPH status but also the numbers of chronic diseases. FHR evaluates the increasing function of the average number of risky behaviors (smoking, drinking, and a sedentary lifestyle), the household's Asymptomatic Objective Health Status (measured as the average number of diseases, blood pressure, blood cholesterol, and osteoporosis), and decreasing function of average household grip strength. Standard errors in parentheses, ${ }^{* * *} p<0.01,{ }^{* *} p<0.05,{ }^{*} p<0.1$. Source: the SHARE data and OECD.Stat (https://stats.oecd.org/Index.aspx). 
Table A7. Marginal effects of purchasing different types of life insurance, whole sample, $\mathrm{N}=34,341$, Age 50+.

\begin{tabular}{|c|c|c|c|c|c|c|c|c|c|c|c|c|}
\hline Dep. var: Life Insurance Holding & Term & Whole & Both & No LI * & Term & Whole & Both & No LI * & Term & Whole & Both & No LI * \\
\hline SPH dummy & $\begin{array}{c}-0.00654 \text { *** } \\
(0.002)\end{array}$ & $\begin{array}{l}0.00203 \\
(0.003)\end{array}$ & $\begin{array}{c}-0.0184 * * * \\
(0.003)\end{array}$ & $\begin{array}{c}0.0229^{* * *} \\
(0.005)\end{array}$ & & & & & & & & \\
\hline OHS & & & & & $\begin{array}{l}0.00182 \\
(0.009)\end{array}$ & $\begin{array}{c}0.000103 \\
(0.012)\end{array}$ & $\begin{array}{c}-0.0289 * * \\
(0.012)\end{array}$ & $\begin{array}{c}0.027 \\
(0.017)\end{array}$ & & & & \\
\hline FHR & & & & & & & & & $\begin{array}{c}-0.006 \text { **** } \\
(0.002)\end{array}$ & $\begin{array}{c}0.000728 \\
(0.002)\end{array}$ & $\begin{array}{c}-0.0105^{* * *} \\
(0.003)\end{array}$ & $\begin{array}{c}.0157 * * * \\
(0.004)\end{array}$ \\
\hline \multicolumn{13}{|l|}{ Demographic variables } \\
\hline Age $\geq 65$ & $\begin{array}{c}-0.0328 * * * \\
(0.003)\end{array}$ & $\begin{array}{c}-0.0344^{* * *} \\
(0.005)\end{array}$ & $\begin{array}{c}-0.0585 * * * \\
(0.005)\end{array}$ & $\begin{array}{c}0.126 * * * \\
(0.007)\end{array}$ & $\begin{array}{c}-0.0335 * * * \\
(0.003)\end{array}$ & $\begin{array}{c}-0.0342 * * * \\
(0.005)\end{array}$ & $\begin{array}{l}-0.0593 * * * * \\
(0.005)\end{array}$ & $\begin{array}{c}0.127 * * * \\
(0.007)\end{array}$ & $\begin{array}{c}-0.0330 \text { **** } \\
(0.003)\end{array}$ & $\begin{array}{c}-0.0343 * * * * \\
(0.005)\end{array}$ & $\begin{array}{c}-0.0597 * * * \\
(0.005)\end{array}$ & $\begin{array}{c}0.127 * * * \\
(0.007)\end{array}$ \\
\hline Higher education & $\begin{array}{c}0.00511^{* * *} \\
(0.002) \\
\end{array}$ & $\begin{array}{c}0.0115 * * * \\
(0.003) \\
\end{array}$ & $\begin{array}{c}0.00691 \text { ** } \\
(0.003)\end{array}$ & $\begin{array}{c}-0.0233 * * * \\
(0.005) \\
\end{array}$ & $\begin{array}{c}0.00569 * * * \\
(0.002)\end{array}$ & $\begin{array}{c}.0113^{* * * *} \\
(0.003) \\
\end{array}$ & $\begin{array}{c}0.00782 \text { ** } \\
(0.003)\end{array}$ & $\begin{array}{c}-0.0249 * * * \\
(0.005)\end{array}$ & $\begin{array}{c}0.00554^{* *} \\
(0.002)\end{array}$ & $\begin{array}{c}0.0114^{* * *} \\
(0.003)\end{array}$ & $\begin{array}{c}0.00788 * * \\
(0.003)\end{array}$ & $\begin{array}{c}-0.0248 * * * \\
(0.005)\end{array}$ \\
\hline \multicolumn{13}{|l|}{ Marital status (ref: Never married) } \\
\hline Married & $\begin{array}{c}0.00909 * * \\
(0.004)\end{array}$ & $\begin{array}{c}0.0324 * * * \\
(0.006)\end{array}$ & $\begin{array}{c}0.0160 * * \\
(0.007)\end{array}$ & $\begin{array}{c}-0.0575 \text { **** } \\
(0.009)\end{array}$ & $\begin{array}{c}0.00924 * * \\
(0.004)\end{array}$ & $\begin{array}{c}0.0325 * * * \\
(0.006)\end{array}$ & $\begin{array}{c}0.0165^{* *} \\
(0.007)\end{array}$ & $\begin{array}{c}-0.0582 \text { *** } \\
(0.009)\end{array}$ & $\begin{array}{c}0.00927 * * \\
(0.004)\end{array}$ & $\begin{array}{c}0.0324 * * * \\
(0.006)\end{array}$ & $\begin{array}{c}0.0166^{* *} \\
(0.007)\end{array}$ & $\begin{array}{c}-0.0583 * * * \\
(0.009)\end{array}$ \\
\hline Divorced & $\begin{array}{c}0.0107 \text { ** } \\
(0.005)\end{array}$ & $\begin{array}{c}0.0148 \text { ** } \\
(0.007)\end{array}$ & $\begin{array}{c}-0.0117 * \\
(0.007)\end{array}$ & $\begin{array}{c}-0.0138 \\
(0.010)\end{array}$ & $\begin{array}{c}0.0108 \text { ** } \\
(0.005)\end{array}$ & $\begin{array}{c}0.0148 \text { ** } \\
(0.007)\end{array}$ & $\begin{array}{l}-0.0115 \\
(0.007)\end{array}$ & $\begin{array}{c}-0.0141 \\
(0.010)\end{array}$ & $\begin{array}{c}0.0108 \text { ** } \\
(0.005)\end{array}$ & $\begin{array}{c}0.0147 \text { ** } \\
(0.007)\end{array}$ & $\begin{array}{c}-0.0115 \\
(0.007)\end{array}$ & $\begin{array}{l}-0.014 \\
(0.010)\end{array}$ \\
\hline Widowed & $\begin{array}{l}0.00183 \\
(0.005)\end{array}$ & $\begin{array}{l}0.0114^{*} \\
(0.007)\end{array}$ & $\begin{array}{c}-0.0191 * * * \\
(0.007)\end{array}$ & $\begin{array}{l}0.00581 \\
(0.010)\end{array}$ & $\begin{array}{l}0.00164 \\
(0.005)\end{array}$ & $\begin{array}{c}0.0115^{*} \\
(0.007)\end{array}$ & $\begin{array}{c}-0.0189 * * * * \\
(0.007)\end{array}$ & $\begin{array}{l}0.00578 \\
(0.010)\end{array}$ & $\begin{array}{l}0.00196 \\
(0.005)\end{array}$ & $\begin{array}{l}0.0115^{*} \\
(0.007)\end{array}$ & $\begin{array}{c}-0.0190 * * * \\
(0.007)\end{array}$ & $\begin{array}{l}0.00556 \\
(0.010)\end{array}$ \\
\hline With children & $\begin{array}{c}0.00680 * * \\
(0.003)\end{array}$ & $\begin{array}{c}-0.00344 \\
(0.006)\end{array}$ & $\begin{array}{c}0.0238^{* * * *} \\
(0.005)\end{array}$ & $\begin{array}{c}-0.0271 * * * * \\
(0.008)\end{array}$ & $\begin{array}{c}0.00698 * * \\
(0.003)\end{array}$ & $\begin{array}{c}-0.00356 \\
(0.006)\end{array}$ & $\begin{array}{c}0.0241 * * * \\
(0.005)\end{array}$ & $\begin{array}{c}-0.0277 \text { *** } \\
(0.008)\end{array}$ & $\begin{array}{c}0.00696 * * \\
(0.003)\end{array}$ & $\begin{array}{c}-0.00357 \\
(0.006)\end{array}$ & $\begin{array}{c}0.0242 * * * \\
(0.005)\end{array}$ & $\begin{array}{c}-0.0276 * * * \\
(0.008)\end{array}$ \\
\hline Household income per capita & $\begin{array}{c}0.00575 * * * \\
(0.001)\end{array}$ & $\begin{array}{c}0.00520 * * * \\
(0.002)\end{array}$ & $\begin{array}{c}0.0102 * * * \\
(0.002)\end{array}$ & $\begin{array}{c}-0.0212 \text { **** } \\
(0.003)\end{array}$ & $\begin{array}{c}0.00604 * * * \\
(0.001)\end{array}$ & $\begin{array}{c}0.00511 \text { **** } \\
(0.002)\end{array}$ & $\begin{array}{c}0.0111^{* * *} \\
(0.002)\end{array}$ & $\begin{array}{c}-0.0222 * * * \\
(0.003)\end{array}$ & $\begin{array}{c}0.00596 * * * \\
(0.001)\end{array}$ & $\begin{array}{c}0.00513^{* * * *} \\
(0.002)\end{array}$ & $\begin{array}{c}0.0110^{* * *} \\
(0.002)\end{array}$ & $\begin{array}{c}-0.0221 \text { *** } \\
(0.003)\end{array}$ \\
\hline Household income per capita squared & $\begin{array}{c}0.000 \\
(0.000)\end{array}$ & $\begin{array}{c}0.000 \\
(0.000)\end{array}$ & $\begin{array}{c}0.000 \\
(0.000)\end{array}$ & $\begin{array}{c}0.000 \\
(0.000)\end{array}$ & $\begin{array}{c}0.000 \\
(0.000)\end{array}$ & $\begin{array}{c}0.000 \\
(0.000)\end{array}$ & $\begin{array}{c}0.000 \\
(0.000)\end{array}$ & $\begin{array}{c}0.000 \\
(0.000)\end{array}$ & $\begin{array}{c}0.000 \\
(0.000)\end{array}$ & $\begin{array}{c}0.000 \\
(0.000)\end{array}$ & $\begin{array}{c}0.000 \\
(0.000)\end{array}$ & $\begin{array}{c}0.000 \\
(0.000)\end{array}$ \\
\hline Net wealth per capita & $\begin{array}{c}0.00468 * * * \\
(0.001) \\
\end{array}$ & $\begin{array}{c}0.00870 * * * \\
(0.001)\end{array}$ & $\begin{array}{c}0.00242 * * * \\
(0.001)\end{array}$ & $\begin{array}{c}-0.0158 * * * \\
(0.001)\end{array}$ & $\begin{array}{c}0.00480 * * * \\
(0.001)\end{array}$ & $\begin{array}{c}0.00865 * * * \\
(0.001)\end{array}$ & $\begin{array}{c}0.00261 \text { *** } \\
(0.001)\end{array}$ & $\begin{array}{c}-0.01616 * * * \\
(0.001)\end{array}$ & $\begin{array}{c}0.004755^{* * * *} \\
(0.001)\end{array}$ & $\begin{array}{c}0.00865 \text { *** } \\
(0.001)\end{array}$ & $\begin{array}{c}0.00258 * * * \\
(0.001)\end{array}$ & $\begin{array}{c}-0.0160 * * * \\
(0.001)\end{array}$ \\
\hline Net wealth per capita squared & $\begin{array}{c}0.000 \\
(0.000)\end{array}$ & $\begin{array}{c}0.000 \\
(0.000)\end{array}$ & $\begin{array}{c}0.000 \\
(0.000)\end{array}$ & $\begin{array}{c}0.000 \\
(0.000)\end{array}$ & $\begin{array}{c}0.000 \\
(0.000)\end{array}$ & $\begin{array}{c}0.000 \\
(0.000)\end{array}$ & $\begin{array}{c}0.000 \\
(0.000)\end{array}$ & $\begin{array}{c}0.000 \\
(0.000)\end{array}$ & $\begin{array}{c}0.000 \\
(0.000)\end{array}$ & $\begin{array}{c}0.000 \\
(0.000)\end{array}$ & $\begin{array}{c}0.000 \\
(0.000)\end{array}$ & $\begin{array}{c}0.000 \\
(0.000)\end{array}$ \\
\hline Prob. of receiving inheritance & $\begin{array}{c}0.00013^{* * * *} \\
(0.000)\end{array}$ & $\begin{array}{c}0.00029 * * * \\
(0.000)\end{array}$ & $\begin{array}{c}0.00024 * * * \\
(0.000)\end{array}$ & $\begin{array}{c}-0.0006 * * * * \\
(0.000)\end{array}$ & $\begin{array}{c}0.00014 * * * \\
(0.000)\end{array}$ & $\begin{array}{c}0.00028^{* * *} \\
(0.000)\end{array}$ & $\begin{array}{c}0.00024 * * * \\
(0.000)\end{array}$ & $\begin{array}{c}-0.00067 \text { *** } \\
(0.000)\end{array}$ & $\begin{array}{c}0.00013 \text { *** } \\
(0.000)\end{array}$ & $\begin{array}{c}0.00028 * * * \\
(0.000)\end{array}$ & $\begin{array}{c}0.00024 * * * \\
(0.000)\end{array}$ & $\begin{array}{c}-0.0007 * * * \\
(0.000)\end{array}$ \\
\hline Pension & $\begin{array}{c}-0.000757 \text { ** } \\
(0.000)\end{array}$ & $\begin{array}{c}-0.00147 * * * \\
(0.000)\end{array}$ & $\begin{array}{c}-0.00220 * * * \\
(0.000)\end{array}$ & $\begin{array}{c}0.00443 * * * * \\
(0.001)\end{array}$ & $\begin{array}{c}-0.000744 \text { ** } \\
(0.000)\end{array}$ & $\begin{array}{c}-0.00147 * * * \\
(0.000)\end{array}$ & $\begin{array}{c}-0.00215 * * * \\
(0.000)\end{array}$ & $\begin{array}{c}0.00436 \text { *** } \\
(0.001)\end{array}$ & $\begin{array}{c}-0.000757 \text { ** } \\
(0.000)\end{array}$ & $\begin{array}{c}-0.00146^{* * *} \\
(0.000)\end{array}$ & $\begin{array}{c}-0.00221 * * * \\
(0.000)\end{array}$ & $\begin{array}{c}0.0044 * * * \\
(0.001)\end{array}$ \\
\hline Future retirement age & $\begin{array}{c}-0.00622 * * * \\
(0.001)\end{array}$ & $\begin{array}{c}-0.00318^{* * *} \\
(0.001)\end{array}$ & $\begin{array}{c}-0.00624^{* * *} \\
(0.001)\end{array}$ & $\begin{array}{c}0.0156^{* * * *} \\
(0.001)\end{array}$ & $\begin{array}{c}-0.00624^{* * *} \\
(0.001)\end{array}$ & $\begin{array}{c}-0.00317^{* * *} \\
(0.001)\end{array}$ & $\begin{array}{c}-0.00624^{* * *} \\
(0.001)\end{array}$ & $\begin{array}{c}0.0157 \text { *** } \\
(0.001)\end{array}$ & $\begin{array}{c}-0.00628^{* * *} \\
(0.001)\end{array}$ & $\begin{array}{c}-0.00317^{* * *} \\
(0.001)\end{array}$ & $\begin{array}{c}-0.00640^{* * *} \\
(0.001)\end{array}$ & $\begin{array}{c}0.0159 * * * \\
(0.001)\end{array}$ \\
\hline Gross pension replacement rate & $\begin{array}{c}0.00148 \text { *** } \\
(0.000)\end{array}$ & $\begin{array}{c}-0.00088^{* * *} \\
(0.000)\end{array}$ & $\begin{array}{c}-0.000092 \\
(0.000)\end{array}$ & $\begin{array}{c}-0.00050 \text { **** } \\
(0.000)\end{array}$ & $\begin{array}{c}0.00148^{* * *} \\
(0.000)\end{array}$ & $\begin{array}{c}-0.00088^{* * *} \\
(0.000)\end{array}$ & $\begin{array}{c}-0.000098 \\
(0.000)\end{array}$ & $\begin{array}{c}-0.000495 \text { ** } \\
(0.000)\end{array}$ & $\begin{array}{c}0.00149 * * * \\
(0.000)\end{array}$ & $\begin{array}{c}-0.000885 \text { *** } \\
(0.000)\end{array}$ & $\begin{array}{c}-0.0000812 \\
(0.000)\end{array}$ & $\begin{array}{c}-0.000520 \text { *** } \\
(0.000)\end{array}$ \\
\hline Health spending from coverage & $\begin{array}{c}-0.0423 * * * \\
(0.004)\end{array}$ & $\begin{array}{c}0.0640^{* * *} \\
(0.005)\end{array}$ & $\begin{array}{c}0.0572^{* * *} \\
(0.005)\end{array}$ & $\begin{array}{c}-0.0789^{* * *} \\
(0.008)\end{array}$ & $\begin{array}{c}-0.0425 * * * \\
(0.004)\end{array}$ & $\begin{array}{c}0.0640^{* * *} \\
(0.005)\end{array}$ & $\begin{array}{c}0.0579 * * * * \\
(0.005)\end{array}$ & $\begin{array}{c}-0.0794^{* * *} \\
(0.008)\end{array}$ & $\begin{array}{c}-0.0425 * * * \\
(0.004)\end{array}$ & $\begin{array}{c}0.0641^{* * *} \\
(0.005)\end{array}$ & $\begin{array}{c}0.0585 \text { *** } \\
(0.005)\end{array}$ & $\begin{array}{c}-0.0800 * * * \\
(0.008)\end{array}$ \\
\hline Out-of-pocket health spending & $\begin{array}{c}0.0267^{* * *} \\
(0.004)\end{array}$ & $\begin{array}{c}-0.0335 * * * \\
(0.005)\end{array}$ & $\begin{array}{c}-0.0780 \text { *** } \\
(0.006)\end{array}$ & $\begin{array}{c}0.0848 * * * \\
(0.008)\end{array}$ & $\begin{array}{c}0.0268^{* * *} \\
(0.004)\end{array}$ & $\begin{array}{c}-0.0334 \text { *** } \\
(0.005)\end{array}$ & $\begin{array}{c}-0.0784^{* * * *} \\
(0.006)\end{array}$ & $\begin{array}{c}0.0850 \text { **** } \\
(0.008)\end{array}$ & $\begin{array}{c}0.0268^{* * *} \\
(0.004)\end{array}$ & $\begin{array}{c}-0.0335 \text { *** } \\
(0.005)\end{array}$ & $\begin{array}{c}-0.0788^{* * *} \\
(0.006)\end{array}$ & $\begin{array}{c}0.0855 \text { *** } \\
(0.008)\end{array}$ \\
\hline Higher Life expectancy & $\begin{array}{c}0.00629 * * \\
(0.003)\end{array}$ & $\begin{array}{c}0.0183 * * * \\
(0.003)\end{array}$ & $\begin{array}{c}0.0123 * * * \\
(0.003)\end{array}$ & $\begin{array}{c}-0.0369 * * * * \\
(0.005)\end{array}$ & $\begin{array}{c}0.00761 * * * \\
(0.003)\end{array}$ & $\begin{array}{c}0.0180 * * * \\
(0.003)\end{array}$ & $\begin{array}{c}0.0145^{* * * *} \\
(0.003)\end{array}$ & $\begin{array}{c}-0.0400 * * * \\
(0.005)\end{array}$ & $\begin{array}{c}0.00711^{* * * *} \\
(0.003)\end{array}$ & $\begin{array}{c}0.0180 * * * \\
(0.003)\end{array}$ & $\begin{array}{c}0.0150 * * * \\
(0.003)\end{array}$ & $\begin{array}{c}-0.0402 * * * * \\
(0.005)\end{array}$ \\
\hline Social activity & $\begin{array}{c}0.0193 * * * \\
(0.002)\end{array}$ & $\begin{array}{c}0.00757 * * \\
(0.003)\end{array}$ & $\begin{array}{c}0.0130 * * * \\
(0.003)\end{array}$ & $\begin{array}{c}-0.0398 * * * * \\
(0.005)\end{array}$ & $\begin{array}{c}0.0201 * * * \\
(0.002)\end{array}$ & $\begin{array}{c}0.00734^{* *} \\
(0.003)\end{array}$ & $\begin{array}{c}0.0148 * * * \\
(0.003)\end{array}$ & $\begin{array}{c}-0.0422 \text { *** } \\
(0.005)\end{array}$ & $\begin{array}{c}0.0197 * * * \\
(0.002)\end{array}$ & $\begin{array}{c}0.00735 \text { ** } \\
(0.003)\end{array}$ & $\begin{array}{c}0.0148 * * * \\
(0.003)\end{array}$ & $\begin{array}{c}-0.0418^{* * *} \\
(0.005)\end{array}$ \\
\hline
\end{tabular}


Table A7. Cont.

\begin{tabular}{|c|c|c|c|c|c|c|c|c|c|c|c|c|}
\hline Dep. var: Life Insurance Holding & Term & Whole & Both & No LI * & Term & Whole & Both & No LI * & Term & Whole & Both & No LI * \\
\hline Religious participation & $\begin{array}{l}0.00294 \\
(0.003)\end{array}$ & $\begin{array}{c}0.0184^{* * * *} \\
(0.005)\end{array}$ & $\begin{array}{l}0.00332 \\
(0.004)\end{array}$ & $\begin{array}{c}-0.0247 * * * \\
(0.006)\end{array}$ & $\begin{array}{l}0.00308 \\
(0.003)\end{array}$ & $\begin{array}{c}0.0184 * * * \\
(0.005)\end{array}$ & $\begin{array}{l}0.00399 \\
(0.004)\end{array}$ & $\begin{array}{c}-0.0255^{* * *} \\
(0.006)\end{array}$ & $\begin{array}{l}0.00306 \\
(0.003)\end{array}$ & $\begin{array}{c}0.0184^{* * * *} \\
(0.005)\end{array}$ & $\begin{array}{l}0.00383 \\
(0.004)\end{array}$ & $\begin{array}{c}-0.0253 * * * * \\
(0.006)\end{array}$ \\
\hline Advanced markets (ref: Emerging markets) & $\begin{array}{c}0.0449^{* * * *} \\
(0.003)\end{array}$ & $\begin{array}{c}-0.0267 * * * \\
(0.006)\end{array}$ & $\begin{array}{c}0.0144^{* * *} \\
(0.005)\end{array}$ & $\begin{array}{c}-0.0325^{* * *} \\
(0.008)\end{array}$ & $\begin{array}{c}0.0459 * * * \\
(0.003)\end{array}$ & $\begin{array}{c}-0.0269 * * * \\
(0.006)\end{array}$ & $\begin{array}{c}0.0156^{* * *} \\
(0.005)\end{array}$ & $\begin{array}{c}-0.0346^{* * *} \\
(0.008)\end{array}$ & $\begin{array}{c}0.0459 * * * * \\
(0.003)\end{array}$ & $\begin{array}{c}-0.0269 * * * * \\
(0.006)\end{array}$ & $\begin{array}{c}0.0161 * * * \\
(0.005)\end{array}$ & $\begin{array}{c}-0.0351 * * * * \\
(0.008)\end{array}$ \\
\hline Log likelihood & \multicolumn{4}{|c|}{$-22,422.112$} & \multicolumn{4}{|c|}{$-22,439.99$} & \multicolumn{4}{|c|}{$-22,430.01$} \\
\hline
\end{tabular}

Note: Mean marginal effects evaluated at each observation. ${ }^{*}$ No LI means households without life insurance. Monetary amounts are PPP-adjusted and in thousand Euros. The dummy $\mathrm{SPH}$ variable refers to SPH $=1$ if poor health (indicating level 3, 4, or 5) and SPH = 0 if good health (indicating level 1 for very good, 2 for good). OHS variable is the determinant of current overall health as this variable not only considers the SPH status but also the numbers of chronic diseases. FHR evaluates the increasing function of the average number of risky behaviors (smoking, drinking, and a sedentary lifestyle), the household's Asymptomatic Objective Health Status (measured as the average number of diseases, blood pressure, blood cholesterol, and osteoporosis), and decreasing function of average household grip strength. Standard errors in parentheses, ${ }^{* * *} p<0.01, * * p<0.05,{ }^{*} p<0.1$. Source: the SHARE data and OECD.Stat (https://stats.oecd.org/Index.aspx). 


\section{References}

1. Yaari, M.E. Uncertain lifetime, life insurance, and the theory of the consumer. Rev. Econ. Stud. 1965, 32, 137-150. [CrossRef]

2. Parrish, S. Permanent life insurance in financial planning: Time for a new model. J. Financ. Serv. Prof. 2014, 68, 30-32.

3. Fang, H.; Keane, M.P.; Silverman, D. Sources of Advantageous Selection: Evidence from the Medigap Insurance Market. J. Political Econ. 2008, 116, 303-350. [CrossRef]

4. Paccagnella, O.; Rebba, V.; Weber, G. Voluntary private health insurance among the over 50s in Europe. Health Econ. 2013, 22, 289-315. [CrossRef] [PubMed]

5. Buchmueller, T.C.; Fiebig, D.G.; Jones, G.; Savage, E. Preference heterogeneity and selection in private health insurance: The case of Australia. J. Health Econ. 2013, 32, 757-767. [CrossRef] [PubMed]

6. Su, B.; Thierry, G.H.; Chen, Q.; Zhao, Q. The new cooperative medical scheme and self-employment in rural China. Sustainability 2017, 9, 304. [CrossRef]

7. Atella, V.; Brunetti, M.; Maestas, N. Household portfolio choices, health status and health care systems: A cross-country analysis based on SHARE. J. Bank. Financ. 2012, 36, 1320-1335. [CrossRef] [PubMed]

8. Bressan, S.; Pace, N.; Pelizzon, L. Health status and portfolio choice: Is their relationship economically relevant? Int. Rev. Financ. Anal. 2014, 32, 109-122. [CrossRef]

9. Beck, T.; Webb, I. Economic, demographic, and institutional determinants of life insurance consumption across countries. World Bank Econ. Rev. 2003, 17, 51-88. [CrossRef]

10. Hwang, T.; Greenford, B. A cross-section analysis of the determinants of life insurance consumption in Mainland China, Hong Kong, and Taiwan. Risk Manag. Insur. Rev. 2005, 8, 103-125. [CrossRef]

11. Li, D.; Moshirian, F.; Nguyen, P.; Wee, T. The demand for life insurance in OECD countries. J. Risk Insur. 2007, 74, 637-652. [CrossRef]

12. Kjosevski, J. The determinants of life insurance demand in central and southeastern Europe. Int. J. Econ. Financ. 2012, 4, 237-247. [CrossRef]

13. Sauter, N.; Walliser, J.; Winter, J. Tax incentives, bequest motives, and the demand for life insurance: Evidence from a natural experiment in Germany. J. Pension Econ. Financ. 2015, 14, 525-553. [CrossRef]

14. Jappelli, T.; Pistaferri, L. Tax incentives and the demand for life insurance: Evidence from Italy. J. Public Econ. 2003, 87, 1779-1799. [CrossRef]

15. Fang, H.; Kung, E. Why Do Life Insurance Policyholders Lapse? The Roles of Income, Health and Bequest Motive Shocks; NBER Working Paper; National Bureau of Economic Research: Cambridge, MA, USA, 2012.

16. Lindström, M. Marital status, social capital, material conditions and self-rated health: A population-based study. Health Policy 2009, 93, 172-179. [CrossRef] [PubMed]

17. Vuong, Q.H.; Vuong, T.T.; Ho, T.M.; Nguyen, H.V. Psychological and socio-economic factors affecting social sustainability through impacts on perceived health care quality and public health: The case of Vietnam. Sustainability 2017, 9, 1456. [CrossRef]

18. Wu, S.; Wang, R.; Zhao, Y.; Ma, X.; Wu, M.; Yan, X.; He, J. The relationship between self-rated health and objective health status: A population-based study. BMC Public Health 2013, 13, 320. [CrossRef] [PubMed]

19. Goldman, D.; Maestas, N. Medical expenditure risk and household portfolio choice. J. Appl. Econ. 2013, 28, 527-550. [CrossRef] [PubMed]

20. Rosen, H.S.; Wu, S. Portfolio choice and health status. J. Financ. Econ. 2004, 72, 457-484. [CrossRef]

21. Edwards, R.D. Health risk and portfolio choice. J. Bus. Econ. Stat. 2008, 26, 472-485. [CrossRef]

22. Cardak, B.A.; Wilkins, R. The determinants of household risky asset holdings: Australian evidence on background risk and other factors. J. Bank. Financ. 2009, 33, 850-860. [CrossRef]

23. Fan, E.; Zhao, R. Health status and portfolio choice: Causality or heterogeneity? J. Bank. Financ. 2009, 33, 1079-1088. [CrossRef]

24. Christelis, D.; Jappelli, T.; Padula, M. Cognitive abilities and portfolio choice. Eur. Econ. Rev. 2010, 54, 18-38. [CrossRef]

25. Çelik, S.; Kayali, M.M. Determinants of demand for life insurance in European countries. Probl. Perspect. Manag. 2009, 7, 32-37.

26. Zietz, E.N. An examination of the demand for life insurance. Risk Manag. Insur. Rev. 2003, 6, $159-191$. [CrossRef] 
27. Inkmann, J.; Michaelides, A. Can the life insurance market provide evidence for a bequest motive? J. Risk Insur. 2012, 79, 671-695. [CrossRef]

28. Shi, X.; Wang, H.J.; Xing, C. The role of life insurance in an emerging economy: Human capital protection, assets allocation and social interaction. J. Bank. Financ. 2015, 50, 19-33. [CrossRef]

29. Ward, D.; Zurbruegg, R. Law, politics and life insurance consumption in Asia. Geneva Pap. Risk Insur. Issues Pract. 2002, 27, 395-412. [CrossRef]

30. Heo, W.; Grable, J.E.; Swarn, C. Life insurance consumption as a function of wealth change. Financ. Serv. Rev. 2013, 22, 389-404.

31. Sommer, M. Savings Motives and the Effectiveness of Tax Incentives-An Analysis Based on the Demand for Life Insurance in Germany; MEA Discussion Papers; Fakultät für Rechtswissenschaft und Volkswirtschaftslehre: Mannheim, Germany, 2007.

32. Andersson, L.F.; Eriksson, L. The compulsory public pension and the demand for life insurance: The case of Sweden, 1884-1914. Econ. Hist. Rev. 2015, 68, 244-263. [CrossRef]

33. Burnett, J.J.; Palmer, B.A. Examining life insurance ownership through demographic and psychographic characteristics. J. Risk Insur. 1984, 51, 453-467. [CrossRef]

34. Browne, M.J.; Kim, K. An international analysis of life insurance demand. J. Risk Insur. 1993, 60, 616-634. [CrossRef]

35. Loke, Y.J.; Goh, Y.Y. Purchase decision of life insurance policies among Malaysians. Int. J. Soc. Sci. Hum. 2012, 2, 415-420. [CrossRef]

36. Börsch-Supan, A.; Hank, K.; Jürges, H. A new comprehensive and international view on ageing: Introducing the 'Survey of Health, Ageing and Retirement in Europe'. Eur. J. Ageing 2005, 2, 245-253. [CrossRef] [PubMed]

37. Zhang, Y.H.; Li, C.S.; Liu, C.C.; Peng, S.C. The impact of health on work in China: A study using pilot survey data. Geneva Pap. Risk Insur. Issues Pract. 2013, 38, 857-870. [CrossRef]

38. Sprangers, M.A.; de Regt, E.B.; Andries, F.; van Agt, H.M.; Bijl, R.V.; de Boer, J.B.; Miedema, H.S. Which chronic conditions are associated with better or poorer quality of life? J. Clin. Epidemiol. 2000, 53, 895-907. [CrossRef]

39. Bliss, C.I. The method of probits. Science 1934, 79, 38-39. [CrossRef] [PubMed]

40. Barasinska, N.; Schäfer, D.; Stephan, A. Individual risk attitudes and the composition of financial portfolios: Evidence from German household portfolios. Q. Rev. Econ. Financ. 2012, 52, 1-14. [CrossRef] 